\title{
Analysis of anabolic steroids in the horse: Development of a generic ELISA for the screening of $17 \alpha$-alkyl anabolic steroid metabolites
}

\author{
Natasha L. Hungerford ${ }^{a}$, Benoît Sortais ${ }^{a}$, Corrine G. Smart ${ }^{b}$, Andrew R. McKinney ${ }^{a, b}$, \\ Damon D. Ridley ${ }^{\mathrm{a}}$, Allen M. Stenhouse ${ }^{\mathrm{b}}$, Craig J. Suann ${ }^{\mathrm{c}}$, Kellie J. Munn ${ }^{\mathrm{d}}$, \\ Martin N. Sillence ${ }^{\mathrm{d}}$, Malcolm D. McLeod ${ }^{\mathrm{a}, *}$ \\ ${ }^{a}$ School of Chemistry, F11, The University of Sydney, NSW 2006, Australia \\ ${ }^{\mathrm{b}}$ Australian Racing Forensic Laboratory, P.O. Box 528, Kensington, NSW 1465, Australia \\ ${ }^{\mathrm{c}}$ Racing New South Wales, P.O. Box 528, Kensington, NSW 1465, Australia \\ ${ }^{\mathrm{d}}$ School of Agricultural and Veterinary Sciences, Charles Sturt University, Locked Bag 588, Wagga Wagga, NSW 2678, Australia
}

Received 20 December 2004; accepted 17 March 2005

\begin{abstract}
Due to the potential for misuse of a wide range of anabolic steroids in horse racing, a screening test to detect multiple compounds, via a common class of metabolites, would be a valuable forensic tool. An enzyme-linked immunosorbent assay (ELISA) has been developed to detect $17 \alpha$-alkyl anabolic steroid metabolites in equine urine. $16 \beta$-Hydroxymestanolone (16 $\beta, 17 \beta$-dihydroxy-17 $\alpha$-methyl-5 $\alpha$-androstan-3-one) was synthesised in six steps from commercially available epiandrosterone ( $3 \beta$-hydroxy-5 $\alpha$-androstan-17-one). Polyclonal antibodies were raised in sheep, employing mestanolone (17 $\beta$-hydroxy-17 $\alpha$-methyl-5 $\alpha$-androstan-3-one) or 16 $\beta$-hydroxymestanolone conjugated to human serum albumin, via a 3-carboxymethyloxime linker, as antigens. Antibody cross-reactivities were determined by assessing the ability of a library of 54 representative steroids to competitively bind the antibodies. Antibodies raised against $16 \beta$-hydroxymestanolone showed excellent crossreactivities for all of the $16 \beta, 17 \beta$-dihydroxy-17 $\alpha$-methyl steroids analysed and an ELISA has been developed to detect these steroid metabolites. Using this $16 \beta$-hydroxymestanolone assay, urine samples from horses administered with stanozolol $\left(17 \alpha\right.$-methyl-pyrazolo[ $\left.4^{\prime}, 3^{\prime}: 2,3\right]-5 \alpha-$ androstan-17 $\beta$-ol), were analysed raw, following $\beta$-glucuronidase hydrolysis, and following solid-phase extraction (SPE) procedures. The suppressed absorbances observed were consistent with detection of the metabolite $16 \beta$-hydroxystanozolol. Positive screening results were confirmed by comparison with standard LCMS analyses. Antibodies raised against mestanolone were also used to develop an ELISA and this was used to detect metabolites retaining the parent D-ring structure following methandriol ( $17 \alpha$-methylandrost-5-ene-3 $\beta, 17 \beta$-diol) administration. The ELISA methods developed have application as primary screening tools for detection of new and known anabolic steroid metabolites. (C) 2005 Elsevier Ltd. All rights reserved.
\end{abstract}

Keywords: Steroid metabolites; ELISA; 16ß-Hydroxymestanolone; $17 \alpha$-Alkyl anabolic steroid; $16 \beta$-Hydroxy steroid

\section{Introduction}

Anabolic steroids are an important class of performance enhancing drug with potential for misuse in horse racing and other sports. As a result, the integrity of the horse racing industry relies on stringent doping control measures targeting these agents. Typically, the comparison of race day samples

\footnotetext{
* Corresponding author. Fax: +61293516650.

E-mail address: m.mcleod@chem.usyd.edu.au (M.D. McLeod).
}

with authentic standards by chromatographic and mass spectrometric techniques is used to screen for and confirm the presence of banned substances. However, there are a number of limitations to this approach, including the need for lengthy sample preparation prior to chromatographic analysis, and the need for authentic standards, particularly where extensive metabolism makes the detection of the parent steroid difficult or impossible. Importantly, this approach is limited to known chemical entities and may fail to detect new synthetic steroids, highlighting the need for broader screening methods [1]. 


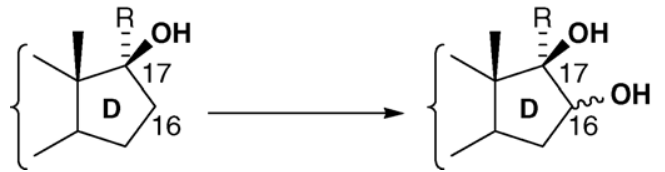

Fig. 1. The common D-ring structure which arises from the metabolism of 17 -alkyl anabolic steroids.

In previous work, techniques such as immunoaffinity chromatography for sample cleanup or immunoassay for rapid primary screening, have been used to provide highly selective and sensitive recognition of steroid analytes [2-8]. A significant advantage of immunological methods is the ability of antibodies to bind broad classes of metabolites that contain a common substructure. In the main, these approaches rely on antibodies produced against antigens derived from the readily available parent drug. As a result, they are only effective in situations where there is minimal biotransformation of the parent substance [9-15].

An important class of anabolic steroid has an alkyl substituent at the 17-position, which imparts oral activity by preventing metabolic conversions of the 17-hydroxyl group, such as oxidation. However, it has been shown [16-28] that these steroids undergo extensive metabolism in horses, cattle and humans, such that little parent steroid is excreted in the urine. Commonly, phase I metabolites result from hydroxylation of the steroid, as well as A-ring reductions. Further, phase
II metabolism involves sulfate or glucuronide conjugation. Of particular relevance to equine analysis, a large number of 17-alkyl steroid phase I metabolites feature a common D-ring structure as a result of 16-hydroxylation (Fig. 1). This pattern is consistent, despite extensive variations in the remainder of the anabolic steroid skeleton, as illustrated in Fig. 2, by the 17-alkyl steroids 1-4 and examples of their corresponding metabolites 5-8.

The aim of this study was to develop a broad screening technique based on immunoassays, to detect the presence of 17-alkyl anabolic steroid metabolites in equine urine. The prevalence of 16-hydroxylated metabolites of $17 \alpha-$ alkyl steroids identifies these 16,17-dihydroxylated steroids as primary targets as antigenic material for immunoassay development. 16 $\beta$-Hydroxymestanolone (9) (Fig. 3) was chosen as the initial representative $16 \beta, 17 \beta$-dihydroxy$17 \alpha$-methyl steroid. Diastereoselective synthesis of $16 \beta$ hydroxymestanolone (9) and conjugation to human serum albumin (HSA), via a (carboxymethyl)oxime tether to the A-ring, provided the antigenic material. The polyclonal antibodies raised were assessed against a panel of steroids to determine cross-reactivity and showed promise for the detection of a broad range of 16-hydroxylated D-ring steroid metabolites. Antibodies against the parent mestanolone (10) were also raised, and showed promise for the detection of metabolites retaining the non-oxidised parent D-ring structure. The enzyme-linked immunosorbent assay (ELISA)
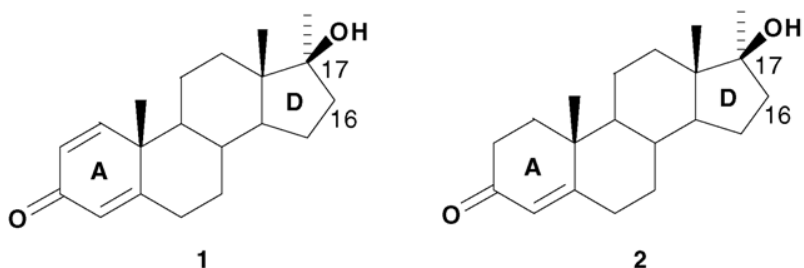

2

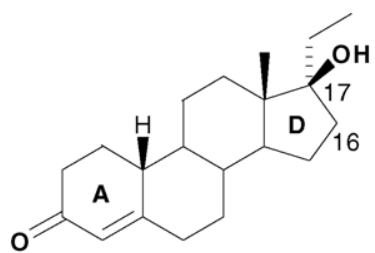

3

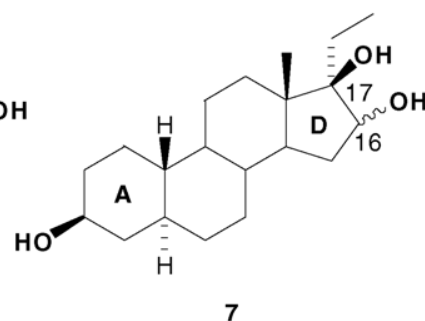

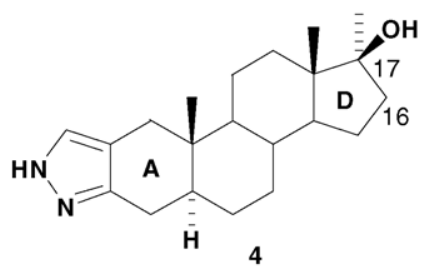

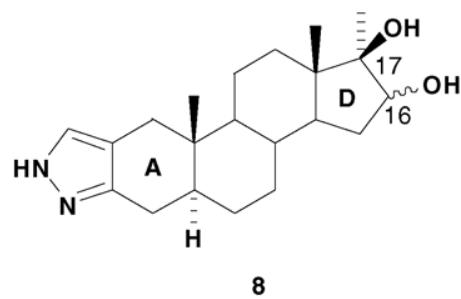

Fig. 2. Representative 17-alkyl steroids 1-4 and examples of their corresponding metabolites 5-8.
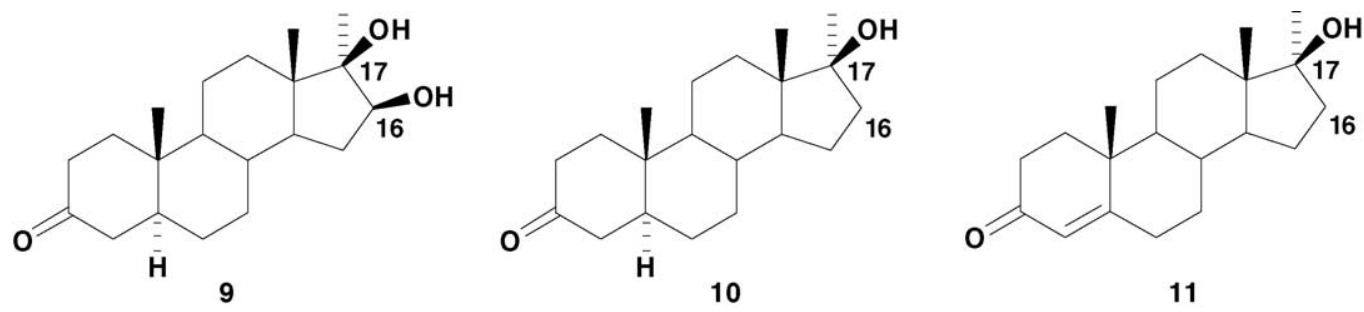

Fig. 3. Steroids conjugated to HSA for immunoassay development. 
methods developed have application as a primary screening tool for the detection of new and known steroid metabolites.

\section{Materials and methods}

\subsection{Chemistry}

\subsubsection{Chemicals}

Epiandrosterone ( $3 \beta$-hydroxy- $5 \alpha$-androstan-17-one) was obtained from Steraloids (Newport, RI, USA). 17 $\alpha$-Methyltestosterone (17 $\beta$-hydroxy-17 $\alpha$-methylandrost-4-en-3-one), mestanolone (17 $\beta$-hydroxy-17 $\alpha$-methyl-5 $\alpha$-androstan-3one), methylmagnesium bromide (3.0 M in diethyl ether), 1[3-(dimethylamino)propyl]-3-ethylcarbodiimide hydrochloride (EDC), 1,3-dicyclohexylcarbodiimide (DCC), human serum albumin, carboxymethoxylamine hemihydrochloride, $N$-hydroxysuccinimide, dialysis tubing $(25 \mathrm{~mm} \times 16 \mathrm{~mm}$ cellulose membrane) and Dowex 50W-X8-100 ion-exchange resin were purchased from Sigma-Aldrich (Castle Hill, NSW, Australia). Phosphate buffer ( $\mathrm{pH} 7.5$ ) was prepared from $\mathrm{KH}_{2} \mathrm{PO}_{4}$ solution $(50 \mathrm{~mL}, 0.1 \mathrm{M})$ and sodium hydroxide solution $(50 \mathrm{~mL}, 0.1 \mathrm{M})$.

\subsubsection{Synthesis}

2.1.2.1. General experimental. Optical rotations were measured using a PolAAR 2001 polarimeter set at the $589.3 \mathrm{~nm}$ sodium D line, in a $0.25 \mathrm{dm}$ cell, in the solvent indicated, and at the concentration $(\mathrm{g} / 100 \mathrm{~mL})$ and temperature indicated. Optical rotations are quoted in $10^{-1} \mathrm{deg} \mathrm{cm}^{2} \mathrm{~g}^{-1}$. Infrared spectra were recorded on a Shimadzu FTIR-8400S Fourier transform infrared spectrometer. Compounds were prepared as thin films or nujol mulls on a $0.5 \mathrm{~cm} \mathrm{NaCl}$ plate, or as $\mathrm{KBr}$ disks, seated on a custom-made perch in the apparatus. Absorption maxima are expressed as wavenumbers $\left(\mathrm{cm}^{-1}\right)$. UV absorbances were recorded from 190 to $820 \mathrm{~nm}$ on a Hewlett-Packard 8452A diode array spectrophotometer.

${ }^{1} \mathrm{H}$ Nuclear magnetic resonance spectra were recorded using a Bruker Avance 200 (200.13 MHz) or a Bruker Avance $300(300.13 \mathrm{MHz})$ spectrometer. Spectra were recorded in $\mathrm{CDCl}_{3}$ or in $\mathrm{CD}_{3} \mathrm{OD}$ and chemical shifts were recorded as $\delta$ values in parts per million ( $\mathrm{ppm}$ ). Signals arising from residual protio-forms of the solvent were used as internal standard ( $\delta 7.26$ and $\delta 3.30$, respectively). Data are reported as chemical shift $(\delta)$, relative integral, multiplicity $(\mathrm{s}=$ singlet, $\mathrm{br}=$ broad, $\mathrm{d}=$ doublet, $\mathrm{t}=$ triplet and $\mathrm{m}=$ multiplet $)$, assignment and coupling constant $(\mathrm{J}$ in $\mathrm{Hz})$. All coupling constants and multiplicities reported are apparent values.

${ }^{13} \mathrm{C}$ Nuclear magnetic resonance spectra were recorded using a Bruker Avance 200 (50.3 MHz) or a Bruker Avance $300(75.5 \mathrm{MHz})$ spectrometer at ambient temperature with complete proton decoupling. Spectra were recorded in $\mathrm{CDCl}_{3}$ or in $\mathrm{CD}_{3} \mathrm{OD}$ and chemical shifts were recorded as $\delta$ values in parts per million. Signals arising from the solvent were used as internal standard ( $\delta 77.0$ and $\delta 49.0$, respectively).
Low-resolution mass spectra were recorded by the Mass Spectrometry Unit, School of Chemistry, The University of Sydney. Major fragments are quoted as mass to charge ratio (assignment, percentage of base peak). Low-resolution mass spectra were recorded on a Finnigan Polaris $Q$ ion trap mass spectrometer, using electron impact (+EI) ionisation mode at $70 \mathrm{eV}$ or on a Finnigan LCQ ion trap mass spectrometer, using positive electrospray ionisation (+ESI) or negative electrospray ionisation (-ESI). High-resolution mass spectra were recorded on a Kratos MS25 RFA mass spectrometer, using electron impact (+EI) ionisation, operating at $70 \mathrm{eV}$, in magnetic scan, with PFK as standard (The University of Queensland), or on a Spectrospin 7T FTICR, using positive or negative electrospray ionisation (The University of New South Wales).

High performance liquid chromatography (HPLC) was carried out using a Waters system consisting of a Model M6000A pump, a millipore model U6K injector, a model 440 ultra-violet detector $(254 \mathrm{~nm})$, and a R401 differential refractometer. Separation was carried out using the solvents indicated, at a flow rate of $1 \mathrm{~mL} \mathrm{~min}^{-1}$, on an Alltech Altima C18 analytical column of inner diameter $4.6 \mathrm{~mm}$, length $25 \mathrm{~mm}$ and particle size $5 \mu \mathrm{m}$.

Analytical thin layer chromatography (TLC) was performed using $0.2 \mathrm{~mm}$ thick, aluminium-backed, precoated silica gel plates (Merck Silica gel $60 \mathrm{~F}_{254}$ ). Compounds were visualised by staining with Goofy's Dip (15 g phosphomolybdic acid, $15 \mathrm{~mL}$ conc. sulfuric acid, $485 \mathrm{~mL}$ water and $2.5 \mathrm{~g}$ cerium sulfate) or an anisaldehyde solution $(7.4 \mathrm{~mL}$ anisaldehyde, $383 \mathrm{~mL}$ ethanol $95 \%, 10 \mathrm{~mL}$ sulfuric acid and $3 \mathrm{~mL}$ acetic acid). Flash chromatography was performed using Merck Silica gel 60 (230-400 mesh ASTM), under a positive pressure of nitrogen, with the solvents indicated. Solvent compositions were mixed (v/v) as specified.

All solvents and reagents were purified according to standard procedures. Moisture sensitive reactions were carried out in oven-dried glassware under a dry, inert nitrogen atmosphere. Reaction temperatures were controlled using dry ice:acetone $\left(-78^{\circ} \mathrm{C}\right)$ or ice:water $\left(0-5^{\circ} \mathrm{C}\right)$ cooling baths. Concentration under reduced pressure refers to evaporation of solvent using a rotary evaporator connected to a water aspirator. Removal of residual solvent where desired, was achieved by evacuation $(0.1-0.01 \mathrm{mmHg})$ with a high-stage, oil-sealed vacuum pump.

2.1.2.2. Synthesis of 16ק-hydroxymestanolone. Compound 13 was prepared in five steps, from commercially available epiandrosterone (3 $\beta$-hydroxy- $5 \alpha$-androstan-17-one) (12) according to published procedures [29-31], with only minor modifications.

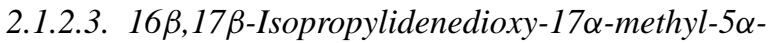
androstan-3-one (13). Compound 13 was synthesised according to the published procedure, from $16 \beta, 17 \beta-$ isopropylidenedioxy- $17 \alpha$-methyl- $5 \alpha$-androstan- $3 \beta$-ol, and was obtained with analytical and spectral data identical to 
those reported previously [29]. $R_{\mathrm{f}} 0.22$ (ethyl acetate/hexane, $1 / 5) ;[\alpha]_{\mathrm{D}}^{22}+16.3$ (c 0.76 , chloroform), \{literature [29]: $[\alpha]_{\mathrm{D}}+15.3$ (c 0.72, chloroform) $\} ; \mathrm{mp}: 174-178^{\circ} \mathrm{C}$ (needles, acetone), (literature [29]: $173.5-176.5^{\circ} \mathrm{C}$ ); $v_{\max }$ (thin film) 2972, 2937, 2856, $1713(\mathrm{C}=\mathrm{O}), 1448,1373,1261,1205$, $1065 \mathrm{~cm}^{-1} ;{ }^{1} \mathrm{H}$ NMR $\left(200 \mathrm{MHz}, \mathrm{CDCl}_{3}\right) \delta: 4.20(1 \mathrm{H}, \mathrm{dd}, J$ 7.5, $\left.4.4 \mathrm{~Hz}, \mathrm{C}_{16} \mathrm{H}\right), 2.48-1.95(6 \mathrm{H}, \mathrm{m}), 1.75-0.58(14 \mathrm{H}, \mathrm{m})$, $1.46\left(3 \mathrm{H}, \mathrm{s}, \mathrm{CH}_{3}\right), 1.36\left(3 \mathrm{H}, \mathrm{s}, \mathrm{CH}_{3}\right), 1.30\left(3 \mathrm{H}, \mathrm{s}, \mathrm{C}_{20} \mathrm{H}\right)$, $1.01\left(3 \mathrm{H}, \mathrm{s}, \mathrm{C}_{18} \mathrm{H}\right), 0.91\left(3 \mathrm{H}, \mathrm{s}, \mathrm{C}_{19} \mathrm{H}\right) ;{ }^{13} \mathrm{C}$ NMR $(50 \mathrm{MHz}$, $\left.\mathrm{CDCl}_{3}\right) \delta: 211.7,112.7,91.1,86.2,53.6,52.3,46.7,44.8$, 44.6, 38.5, 38.1, 35.7, 32.8, 31.5, 31.4, 28.7, 26.3, 25.9, 22.6, 21.1, 15.5, 11.4 (1C overlapping); HRMS (+EI): calc for $\mathrm{C}_{23} \mathrm{H}_{36} \mathrm{O}_{3}\left(M^{+}\right) 360.2664$, found 360.2662; LRMS (+EI) $360\left(M^{+}, 100\right), 345\left(\left[M-\mathrm{CH}_{3}\right]^{+}, 45\right), 285(55), 217(35)$, $127(75)$.

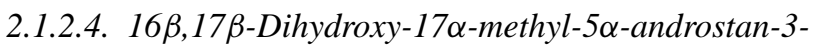
one (16 $\beta$-hydroxymestanolone) (9). A solution of acetonide 13 (440 mg, $1.2 \mathrm{mmol})$ in a mixture of methanol/distilled water $(20 \mathrm{~mL}, 1 / 1)$ was stirred at room temperature under a nitrogen atmosphere. Dowex 50W-X8-100 ion-exchange resin $(880 \mathrm{mg}, 2$ eq. in weight previously washed with a large amount of methanol) was added in one portion, and the resulting reaction mixture was then heated at $70^{\circ} \mathrm{C}$ for $18 \mathrm{~h}$. The mixture was filtered and rinsed with methanol $(2 \times 20 \mathrm{~mL})$ to remove the resin. The mixture was concentrated to ca. $3 \mathrm{~mL}$, poured onto distilled water $(50 \mathrm{~mL})$ and extracted into ethyl acetate $(3 \times 50 \mathrm{~mL})$. The combined organic layers were dried (sodium sulfate) and filtered. Concentration under reduced pressure gave a colourless crude powder $(400 \mathrm{mg})$. Recrystallisation in hot ethyl acetate/hexane afforded a pure mixture of two epimers

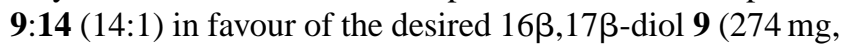
$70 \%)$. For characterisation purposes, separation of the two epimers was achieved by HPLC (hexane/ethyl acetate, $55 / 45$ ) or recrystallisation (ethyl acetate/hexane). 9: $R_{\mathrm{f}} 0.2$ (ethyl acetate/hexane, $1 / 1) ;[\alpha]_{\mathrm{D}}{ }^{20}+8.4$ (c 1.0, dichloromethane); mp: $185-186^{\circ} \mathrm{C}$; $v_{\max }$ (thin film) 3600-3000 (OH), 2939, 2920, 2854, $1713(\mathrm{C}=\mathrm{O}), 1447,1381,1356,1271,1219$, $1175,1124,1067,1040,1024 \mathrm{~cm}^{-1} ;{ }^{1} \mathrm{H}$ NMR $(200 \mathrm{MHz}$, $\left.\mathrm{CDCl}_{3}\right) \delta: 3.64\left(1 \mathrm{H}, \mathrm{dd}, J 7.9,5.4 \mathrm{~Hz}, \mathrm{C}_{16} \mathrm{H}\right), 3.00-2.80$ $(1 \mathrm{H}, \mathrm{br} \mathrm{s}, \mathrm{OH}), 2.80-2.60(1 \mathrm{H}, \mathrm{br} \mathrm{s}, \mathrm{OH}), 2.48-1.92(6 \mathrm{H}$, $\mathrm{m}), 1.78-0.63(14 \mathrm{H}, \mathrm{m}), 1.11\left(3 \mathrm{H}, \mathrm{s}, \mathrm{C}_{20} \mathrm{H}\right), 1.01(3 \mathrm{H}, \mathrm{s}$, $\left.\mathrm{C}_{18} \mathrm{H}\right), 0.86\left(3 \mathrm{H}, \mathrm{s}, \mathrm{C}_{19} \mathrm{H}\right) ;{ }^{13} \mathrm{C}$ NMR $\left(50 \mathrm{MHz}, \mathrm{CDCl}_{3}\right) \delta$ : 212.0, 79.1, 77.6, 53.9, 46.9, 46.7, 44.9, 44.6, 38.5, 38.1, $35.7,35.6,34.8,32.3,31.5,28.7,23.7,20.8,13.5,11.4$; HRMS (+EI): calc for $\mathrm{C}_{20} \mathrm{H}_{32} \mathrm{O}_{3}\left(M^{+}\right) 320.2351$, found 320.2350; LRMS (+EI) $320\left(M^{+}, 85\right), 232$ (60), 217 (100), 159 (45).

\subsubsection{Synthesis of steroid-HSA conjugates.}

General procedure for preparation of (carboxymethyl)oximes 15-17. Carboxymethoxylamine hemihydrochloride $(2 \mathrm{mmol})$ was added to a solution of 9-11 $(1 \mathrm{mmol})$ in pyridine $(10 \mathrm{~mL})$. The reaction mixture was heated to $80^{\circ} \mathrm{C}$ and stirred under a nitrogen atmosphere for $1-2.5 \mathrm{~h}$. The reaction mixture was poured into distilled water $(100 \mathrm{~mL})$ and extracted into ethyl acetate $(3 \times 50 \mathrm{~mL})$. The combined organic layers were washed with saturated copper sulfate solution $(4 \times 30 \mathrm{~mL})$, water $(2 \times 30 \mathrm{~mL})$ and saturated sodium chloride solution $(1 \times 30 \mathrm{~mL})$, and then dried (sodium sulfate) and concentrated to give the product.

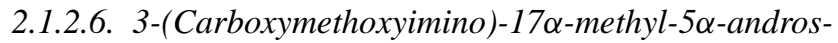

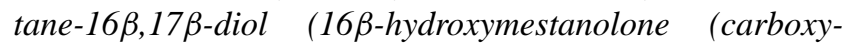
methyl)oxime) (15). 16 16 -Hydroxymestanolone (9) (137 mg, $0.4 \mathrm{mmol})$ in pyridine $(4 \mathrm{~mL})$ was treated as per the general procedure. Flash chromatography (dichloromethane/ methanol, 90/10-80/20) afforded $15(110 \mathrm{mg}, 65 \%)$, as colourless crystals of a 1:1 mixture of isomers. $R_{\mathrm{f}} 0.13$ (ethyl acetate/methanol, 90/10); $[\alpha]_{\mathrm{D}}{ }^{20}+5.2$ (c 1.0, methanol); mp: $227-228^{\circ} \mathrm{C} ; v_{\max }$ (nujol) 3600-2400 (OH), 2921, 2854, $1733(\mathrm{C}=\mathrm{O}), 1263,1097,1026,737 \mathrm{~cm}^{-1}$; ${ }^{1} \mathrm{H} \mathrm{NMR}$ (300 MHz, $\left.\mathrm{CD}_{3} \mathrm{OD}\right) \delta: 4.50\left(2 \mathrm{H}, \mathrm{s}, \mathrm{OCH}_{2} \mathrm{CO}_{2}\right), 3.58(1 \mathrm{H}$, dd, $\left.\mathrm{C}_{16} \mathrm{H}, J 7.9,5.5 \mathrm{~Hz}\right), 3.24,2.99(1 \mathrm{H}, 2 \times \mathrm{m}), 2.27-0.64$ $(19 \mathrm{H}, \mathrm{m}), 1.08\left(3 \mathrm{H}, \mathrm{s}, \mathrm{CH}_{3}\right), 0.95\left(3 \mathrm{H}, \mathrm{s}, \mathrm{CH}_{3}\right), 0.83(3 \mathrm{H}, \mathrm{s}$, $\left.\mathrm{CH}_{3}\right) ;{ }^{13} \mathrm{C}$ NMR $\left(75 \mathrm{MHz}, \mathrm{CD}_{3} \mathrm{OD}\right) \delta: 174.2,163.2,79.9$, 78.4, 70.7, 55.6, 55.5, 48.4, 48.0, 46.8, 46.2, 39.7, 38.5, $37.4,37.3,37.1,35.9,35.1,33.7,32.9,32.8,29.9,29.7$, $29.1,28.4,24.3,22.4,21.7,17.7,14.3,13.8,11.9,11.7$ (11C overlapping); HRMS (-ESI) calc for $\mathrm{C}_{22} \mathrm{H}_{34} \mathrm{NO}_{5}$ $\left([M-\mathrm{H}]^{-}\right)$392.2437, found 392.2433; LRMS (-ESI): 785 $\left([2 M-\mathrm{H}]^{-}, 100\right), 392\left([M-\mathrm{H}]^{-}, 80\right)$.

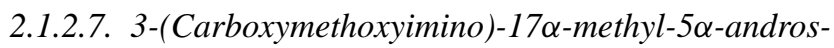
tan-17ß-ol (mestanolone (carboxymethyl)oxime) (16). Commercially available mestanolone (17 $\beta$-hydroxy-17 $\alpha$ methyl-5 $\alpha$-androstan-3-one) (10) (400 mg, $1.3 \mathrm{mmol})$ in pyridine $(13 \mathrm{~mL})$ was treated as per the general procedure. Recrystallisation (ethyl acetate/hexane) afforded colourless, crystalline 16 [32] as a 1:1 mixture of isomers (386 mg, 78\%). $R_{\mathrm{f}} 0.20$ (dichloromethane/methanol, 90/10); $[\alpha]_{\mathrm{D}}{ }^{20}+4.8$ (c 1.0, methanol); mp: $199-200{ }^{\circ} \mathrm{C}$ (literature [32]: $198-199^{\circ} \mathrm{C}$ ); $v_{\max }$ (nujol) 3600-2400 (OH), $1729(\mathrm{C}=\mathrm{O}), 1456,1377,721 \mathrm{~cm}^{-1} ;{ }^{1} \mathrm{H}$ NMR $(300 \mathrm{MHz}$, $\left.\mathrm{CD}_{3} \mathrm{OD}\right) \delta: 4.48\left(2 \mathrm{H}, \mathrm{s}, \mathrm{OCH}_{2} \mathrm{CO}_{2}\right), 2.98,3.03(1 \mathrm{H}, 2 \times \mathrm{m})$, $2.25-0.54(21 \mathrm{H}, \mathrm{m}), 1.18\left(3 \mathrm{H}, \mathrm{s}, \mathrm{CH}_{3}\right), 0.96\left(3 \mathrm{H}, \mathrm{s}, \mathrm{CH}_{3}\right)$, $0.85\left(3 \mathrm{H}, \mathrm{s}, \mathrm{CH}_{3}\right) ;{ }^{13} \mathrm{C} \mathrm{NMR}\left(75 \mathrm{MHz}, \mathrm{CD}_{3} \mathrm{OD}\right) \delta: 174.8$, 163.1, 82.2, 70.8, 55.5, 52.0, 48.6, 46.8, 39.8, 39.2, 38.6, $37.6,37.3,35.1,32.929 .9,29.8,26.1,24.3,22.4,22.0$, 14.7, 11.9, 11.7 (20C overlapping); HRMS (+ESI) calc for $\mathrm{C}_{22} \mathrm{H}_{36} \mathrm{NO}_{4}\left([M+\mathrm{H}]^{+}\right)$378.2644, found 378.2638; LRMS (+ESI): $400\left([M+\mathrm{Na}]^{+}, 30\right), 378\left([M+\mathrm{H}]^{+}, 100\right)$, 349 (23).

\subsubsection{3-(Carboxymethoxyimino)-17 $\alpha$-methylandrost-4-} en-17 $\beta$-ol ( $17 \alpha$-methyltestosterone (carboxymethyl)oxime) (17). Commercially available $17 \alpha$-methyltestosterone $(17 \beta-$ hydroxy-17 $\alpha$-methylandrost-4-en-3-one) (11) (500 mg, $1.65 \mathrm{mmol})$ in pyridine $(15 \mathrm{~mL})$ was treated as per the general procedure. The residue was adsorbed onto silica from 
dichloromethane/methanol (1/1) and subjected to flash chromatography (ethyl acetate/methanol, 90/10-85/15), which gave a 1:2 mixture of $Z$ and $E$ isomers of $17(557 \mathrm{mg}, 90 \%)$, as colourless crystals. $R_{\mathrm{f}} 0.1$ (ethyl acetate/methanol, 90/10); $[\alpha]_{\mathrm{D}}{ }^{20}+124.4$ (c 0.55, methanol); mp: $166-168^{\circ} \mathrm{C} ; v_{\max }$ (KBr) 3600-2400 (OH), 2936, $1730(\mathrm{C}=\mathrm{O}), 1627,1448$, $1375,1099 \mathrm{~cm}^{-1} ;{ }^{1} \mathrm{H}$ NMR $\left(300 \mathrm{MHz}, \mathrm{CD}_{3} \mathrm{OD}\right) \delta: 6.45$, $5.70(1 \mathrm{H}, 2 \times \mathrm{s}, \mathrm{CH}=), 4.53,4.50\left(2 \mathrm{H}, 2 \times \mathrm{s}, \mathrm{OCH}_{2} \mathrm{CO}_{2}\right)$, $3.07,3.02(1 \mathrm{H}, 2 \times \mathrm{m}), 2.47-2.11(4 \mathrm{H}, \mathrm{m}), 1.98-1.75(4 \mathrm{H}$, $\mathrm{m}), 1.70-0.76(10 \mathrm{H}, \mathrm{m}), 1.17,1.15,1.11,0.88(9 \mathrm{H}, 4 \times \mathrm{s}$, $\left.3 \times \mathrm{CH}_{3}\right) ;{ }^{13} \mathrm{C}$ NMR $\left(75 \mathrm{MHz}, \mathrm{CD}_{3} \mathrm{OD}: \mathrm{CDCl}_{3} / 3: 1\right) \quad \delta$ : 173.9, 161.7, 159.0, 158.1, 155.9, 117.3, 111.8, 81.93, 81.9, 71.0, 70.8, 55.1, 54.9, 51.4, 51.3, 46.4, 46.3, 39.8, 38.9, 37.6, $37.5,37.1,35.5,33.8,33.3,33.2,32.9,32.4,26.0,25.1$, 24.0, 21.9, 21.7, 20.3, 18.4, 18.2, 14.5 (7C overlapping); HRMS (+ESI) calc for $\mathrm{C}_{22} \mathrm{H}_{34} \mathrm{NO}_{4}\left([M+\mathrm{H}]^{+}\right) 376.2482$, found 376.2478; LRMS (+ESI): $773\left(\left[2 M+\mathrm{Na}^{+}, 40\right), 398\right.$ $\left([M+\mathrm{Na}]^{+}, 45\right), 376\left([M+\mathrm{H}]^{+}, 100\right)$.

General procedure for synthesis of $N$-hydroxysuccinimide derivatives 18-20. $\quad N$-Hydroxysuccinimide (1.1 mmol) was added to a solution of 15-17 $(1 \mathrm{mmol})$ in dioxane $(10 \mathrm{~mL})$ (and dichloromethane $(11 \mathrm{~mL}))$. EDC (1.1 molar eq.) was added and the reaction mixture was stirred at room temperature under nitrogen, for $16-24 \mathrm{~h}$. The reaction mixture was concentrated under reduced pressure. The residue obtained was partitioned between water $(100 \mathrm{~mL})$ and ethyl acetate $(50 \mathrm{~mL})$. The aqueous layer was further extracted with ethyl acetate $(2 \times 50 \mathrm{~mL})$. The combined organic phases were washed with $\mathrm{pH} 7$, buffer $(50 \mathrm{~mL})$ and saturated sodium chloride solution $(50 \mathrm{~mL})$, then dried (sodium sulfate) and concentrated.

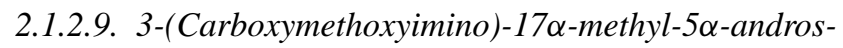
tane-16 $\beta, 17 \beta$-diol $N$-hydroxysuccinimide ester (16 $\beta$-hydroxymestanolone (carboxymethyl)oxime $N$-hydroxysuccinimide ester) (18). Compound 15 (47 mg, $0.12 \mathrm{mmol}$ ) in dichloromethane $(1.5 \mathrm{~mL})$ and dioxane $(1.5 \mathrm{~mL})$ was treated as per the general procedure. Precipitation of the resulting solid from ethyl acetate/hexane gave 18 (40 mg, $68 \%$ ) as a $1: 1$ mixture of isomers. $R_{\mathrm{f}} 0.6$ (ethyl acetate); $[\alpha]_{\mathrm{D}}{ }^{20}+8.8$ (c 0.50, chloroform); mp 88-90 ${ }^{\circ} \mathrm{C} ; v_{\max }$ (thin film) 3700-3000 (OH), 2937, 2856, 1823 (C=O), 1788 $(\mathrm{C}=\mathrm{O}), 1737(\mathrm{C}=\mathrm{O}), 1446,1381,1267,1205,1076 \mathrm{~cm}^{-1}$; ${ }^{1} \mathrm{H}$ NMR $\left(300 \mathrm{MHz}, \mathrm{CDCl}_{3}\right) \delta: 4.87\left(2 \mathrm{H}, \mathrm{s}, \mathrm{OCH}_{2} \mathrm{CO}_{2}\right)$, $3.63\left(1 \mathrm{H}, \mathrm{dd}, \mathrm{C}_{16} \mathrm{H}, J 7.9,5.4 \mathrm{~Hz}\right), 3.18,2.96(1 \mathrm{H}, 2 \times \mathrm{m})$, $2.83\left(4 \mathrm{H}, \mathrm{s}, \mathrm{COCH}_{2} \mathrm{CH}_{2} \mathrm{CO}\right), 2.30-2.80(2 \mathrm{H}$, br s, $2 \times \mathrm{OH})$, 2.32-0.60 (19H, m), $1.11\left(3 \mathrm{H}, \mathrm{s}, \mathrm{CH}_{3}\right), 0.89\left(3 \mathrm{H}, \mathrm{s}, \mathrm{CH}_{3}\right)$, $0.84\left(3 \mathrm{H}, \mathrm{s}, \mathrm{CH}_{3}\right) ;{ }^{13} \mathrm{C} \mathrm{NMR}\left(75 \mathrm{MHz}, \mathrm{CDCl}_{3}\right) \delta: 168.7$, 165.7, 163.0, 162.9, 79.2, 77.7, 67.9, 54.1, 54.0, 47.0, 46.5, $45.3,44.9,38.2,37.3,36.2,36.1,35.6,34.8,33.9,32.4,31.6$, 28.6, 28.4, 28.2, 27.4, 25.6, 23.8, 21.5, 20.6, 20.5, 13.5, 11.5, 11.3 (18C overlapping); HRMS (+EI) calc for $\mathrm{C}_{26} \mathrm{H}_{38} \mathrm{~N}_{2} \mathrm{O}_{7}$ $\left(M^{+}\right)$490.2679, found 490.2679; LRMS (+EI): $490\left(M^{+}\right.$, 18), 447 (35), 318 (20), 300 (12), 282 (16), 256 (20), 230 (60), 202 (35), 157 (25), 91 (100), 79 (35).

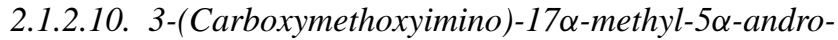
stan-17 $\beta$-ol $N$-hydroxysuccinimide ester (mestanolone (carboxymethyl)oxime N-hydroxysuccinimide ester) (19). Compound 16 (358 mg, $1 \mathrm{mmol})$ in dioxane $(10 \mathrm{~mL})$ was treated as per the general procedure using $N$ hydroxysuccinimide $(218 \mathrm{mg}, 2 \mathrm{mmol})$, except that DCC (391 $\mathrm{mg}, 2 \mathrm{mmol}$ ) was used instead of EDC, and the reaction mixture was filtered prior to concentration and extraction. Flash chromatography (dichloromethane/ethyl acetate, 40/60) of the oily residue afforded 19 (175 $\mathrm{mg}, 39 \%)$, as colourless crystals, and as a 1:1 mixture of isomers. $R_{\mathrm{f}}$ 0.25 (dichloromethane/methanol, $90 / 10) ;[\alpha]_{\mathrm{D}}{ }^{20}+6.2(c 1.0$, dichloromethane); mp: 94-95 ${ }^{\circ} \mathrm{C}$; $v_{\max }$ (nujol) 3700-3000 $(\mathrm{OH}), 1780(\mathrm{C}=\mathrm{O}), 1708(\mathrm{C}=\mathrm{O}), 1215,1085 \mathrm{~cm}^{-1} ;{ }^{1} \mathrm{H}$ NMR $\left(300 \mathrm{MHz}, \mathrm{CDCl}_{3}\right) \delta: 4.88\left(2 \mathrm{H}, \mathrm{s}, \mathrm{OCH}_{2} \mathrm{CO}_{2}\right), 2.99$, $2.95(1 \mathrm{H}, 2 \times \mathrm{m}), 2.84\left(4 \mathrm{H}, \mathrm{s}, \mathrm{COCH}_{2} \mathrm{CH}_{2} \mathrm{CO}\right), 2.37-0.63$ $(22 \mathrm{H}, \mathrm{m}), 1.26\left(3 \mathrm{H}, \mathrm{s}, \mathrm{CH}_{3}\right), 0.90\left(3 \mathrm{H}, \mathrm{s}, \mathrm{CH}_{3}\right), 0.85(3 \mathrm{H}, \mathrm{s}$, $\left.\mathrm{CH}_{3}\right) ;{ }^{13} \mathrm{C} \mathrm{NMR}\left(75 \mathrm{MHz}, \mathrm{CDCl}_{3}\right) \delta: 168.9,165.9,163.3$, 163.2, 81.8, 68.0, 54.1, 54.0, 50.7, 49.4, 46.7, 45.7, 45.6, $39.1,38.5,37.5,36.5,36.4,34.1,31.8,31.7,28.9,28.7$, 28.4, 27.6, 26.0, 25.7, 25.1, 23.4, 21.7, 20.9, 14.1, 11.7, 11.5 (18C overlapping); HRMS (+ESI) calc for $\mathrm{C}_{26} \mathrm{H}_{39} \mathrm{~N}_{2} \mathrm{O}_{6}$ $\left([M+\mathrm{H}]^{+}\right)$475.2808, found 475.2803; LRMS (+ESI): 475 $\left([M+\mathrm{H}]^{+}, 48\right), 453(56), 437$ (100).

\subsubsection{3-(Carboxymethoxyimino)-17 $\alpha$-methylandrost-4-}

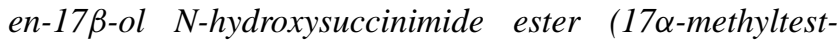
osterone (carboxymethyl)oxime N-hydroxysuccinimide ester) (20). Compound 17 (150 $\mathrm{mg}, 0.40 \mathrm{mmol})$ in dichloromethane $(5 \mathrm{~mL})$ and dioxane $(4 \mathrm{~mL})$ was treated as per the general procedure. Precipitation from ethyl acetate/hexane gave 20 (185 mg, 98\%), as colourless crystals, and as a 1:2 mixture of $Z$ and $E$ isomers. $R_{\mathrm{f}} 0.7$ (ethyl acetate); $[\alpha]_{\mathrm{D}}{ }^{20}+105.9$ (c 0.54 , chloroform); mp: $79-83^{\circ} \mathrm{C}$; $v_{\max }(\mathrm{KBr}) 3700-3000(\mathrm{OH}), 2940,2870,1824(\mathrm{C}=\mathrm{O})$, $1789(\mathrm{C}=\mathrm{O}), 1740(\mathrm{C}=\mathrm{O}), 1630,1448,1431,1376,1205$, $1079 \mathrm{~cm}^{-1} ;{ }^{1} \mathrm{H}$ NMR $\left(300 \mathrm{MHz}, \mathrm{CDCl}_{3}\right) \delta: 6.38,5.72(1 \mathrm{H}$, $2 \times \mathrm{s}, \mathrm{CH}=), 4.89,4.88\left(2 \mathrm{H}, 2 \times \mathrm{s}, \mathrm{OCH}_{2} \mathrm{CO}_{2}\right), 3.03,2.97$ $(1 \mathrm{H}, 2 \times \mathrm{m}), 2.80\left(4 \mathrm{H}, \mathrm{s}, \mathrm{COCH}_{2} \mathrm{CH}_{2} \mathrm{CO}\right), 2.36-2.06(4 \mathrm{H}$, $\mathrm{m}), 1.90-0.72(15 \mathrm{H}, \mathrm{m}), 1.17,1.08,1.04,0.85(9 \mathrm{H}, 4 \times \mathrm{s}$, $\left.3 \times \mathrm{CH}_{3}\right) ;{ }^{13} \mathrm{C} \mathrm{NMR}\left(75 \mathrm{MHz}, \mathrm{CDCl}_{3}\right) \delta: 168.7,165.7$, 165.6, 160.8, 158.5, 157.0, 155.5, 116.4, 110.6, 81.4, 81.39, $68.1,68.0,53.8,53.6,50.2,50.1,45.3,45.2,38.9,38.8$, $37.9,36.5,36.46,35.9,34.5,32.9,32.4,32.1,31.7,31.4$, $31.36,25.7,25.5,24.3,23.1,20.9,20.7,19.4,17.9,17.6$, 13.8 (10C overlapping); HRMS (+EI) calc for $\mathrm{C}_{26} \mathrm{H}_{36} \mathrm{~N}_{2} \mathrm{O}_{6}$ $\left(M^{+}\right)$472.2573, found 472.2567; LRMS (+EI): $472\left(M^{+}\right.$, 50), 457 (15), 300 (100), 282 (65), 266 (28), 242 (30), 209 (35), 157 (34), 131 (36), 120 (44), 105 (33), 91 (43), 79 (38), 77 (30).

\subsubsection{Preparation and storage of the dialysis tubing.} The commercially available dialysis tubing was treated before use. The glycerin residues were removed by washing the tubing in running water for 3-4h. The sulfur compounds were removed by treating the tubing with a sodium sulfide 
solution $(0.3 \%, \mathrm{w} / \mathrm{v})$ at $80^{\circ} \mathrm{C}$ for $1 \mathrm{~min}$. The tubing was then washed with hot distilled water $\left(60^{\circ} \mathrm{C}\right)$ for $2 \mathrm{~min}$, followed by acidification with sulfuric acid $(0.2 \%$, v/v). Finally, the membrane was rinsed with hot distilled water to remove the acid. The resulting soft cellulose membrane can be stored several months in a solution of sodium azide $(0.1 \%$, w/v). The dialysis tubing was rinsed several times with distilled water prior to use.

General procedure for preparation of the steroid-HSA conjugates 21-23 from the carboxylic acid derivatives 15-17. EDC $(0.07 \mathrm{mmol})$ in distilled water $(1.0 \mathrm{~mL})$ was added dropwise to carboxylic acid (15-17) $(0.06 \mathrm{mmol})$ in dioxane $(3.0 \mathrm{~mL})$ and stirred for $30 \mathrm{~min}$, at room temperature $[33,34]$. HSA (1.5 eq., w/w with carboxylic acid 15-17) in phosphate buffer pH $7.5(0.1 \mathrm{M}, 3.0 \mathrm{~mL})$ was added dropwise and the reaction mixture was stirred for $20 \mathrm{~h}$. An additional quantity of solid EDC (0.04 mmol) was added and stirring was continued for $4 \mathrm{~h}$. The reaction mixture was transferred to dialysis tubing and dialysed against stirred, distilled water (500 times the initial volume). The water was changed after 2, 4, 22, 48 and $72 \mathrm{~h}$. The solution contained in the dialysis tubing was then utilised.

2.1.2.13. Human serum albumin-conjugate (21). Carboxylic acid $15(24 \mathrm{mg}, 0.06 \mathrm{mmol})$ was treated as per the general procedure, using dioxane ( $3 \mathrm{~mL})$, EDC (13 mg, 0.07 mmol) in distilled water ( $1 \mathrm{~mL})$ and HSA (36 mg, 1.5 eq., w/w) in phosphate buffer $\mathrm{pH} 7.5(0.1 \mathrm{M}, 3 \mathrm{~mL})$. Following dialysis, the mixture was lyophilised to give conjugate 21 (43 mg), as a colourless powder.

2.1.2.14. Human serum albumin-conjugate (22). Carboxylic acid $16(10 \mathrm{mg}, 0.03 \mathrm{mmol})$ was treated as per the general procedure, using dioxane $(2 \mathrm{~mL})$, EDC $(6 \mathrm{mg}$, $0.03 \mathrm{mmol})$ in distilled water $(0.5 \mathrm{~mL})$ and HSA $(15 \mathrm{mg}$, 1.5 eq., w/w) in phosphate buffer $\mathrm{pH} 7.5(0.1 \mathrm{M}, 2 \mathrm{~mL})$. Following dialysis, the mixture was lyophilised to give conjugate 22 (16 mg), as a colourless powder.

2.1.2.15. Human serum albumin-conjugate (23). Carboxylic acid 17 ( $24 \mathrm{mg}, 0.064 \mathrm{mmol})$ was treated as per the general procedure, using dioxane $(3 \mathrm{~mL})$, EDC $(13.5 \mathrm{mg}$, $0.070 \mathrm{mmol})$ in distilled water $(1.0 \mathrm{~mL})$ and HSA $(36 \mathrm{mg}, 1.5$ eq., w/w) in phosphate buffer $\mathrm{pH} 7.5(0.1 \mathrm{M}, 3.0 \mathrm{~mL})$. The solution contained in the dialysis tubing was then adjusted to $\mathrm{pH} 4.5$ with $1 \mathrm{M} \mathrm{HCl}$ solution (two drops). A colourless precipitate was observed and after the addition of acetone $(100 \mu \mathrm{L})$ and solid sodium chloride $(2 \mathrm{mg})$, the mixture was centrifuged $(2000 \times g$ for $20 \mathrm{~min})$. The supernatant was collected and the precipitate was resuspended in distilled water. Acetone $(100 \mu \mathrm{L})$ and solid sodium chloride $(2 \mathrm{mg})$ were added, and the centrifugation process was repeated twice. The precipitate obtained was redissolved in water $(2.0 \mathrm{~mL})$ by the addition of a minimal quantity of saturated sodium hydrogencarbonate solution. The resulting clear solution was lyophilised to give $\mathbf{2 3 a}$, as a colourless powder $(13 \mathrm{mg})$. Lyophilisation of the combined supernatants afforded 23b (46 mg) as a colourless powder.

General procedure for preparation of the steroid-HSA conjugates 24-26 from the $N$-hydroxysuccinimide ester derivatives 18-20. HSA (2.5 eq., w/w) was dissolved in phosphate buffer pH $7.5(0.05 \mathrm{M}, 1.0 \mathrm{~mL})$ and cooled to $4{ }^{\circ} \mathrm{C}[34,35] . N$-Hydroxysuccinimide ester derivative (18-20) $(0.05 \mathrm{mmol})$ in DMF $(1.5 \mathrm{~mL})$ was added dropwise. The reaction mixture was stirred between 2 and $7^{\circ} \mathrm{C}$ for $12-24 \mathrm{~h}$. The reaction mixture was transferred to dialysis tubing and dialysed against stirred, distilled water (500 times the initial volume). The water was changed after 2, 4, 22, 48 and $72 \mathrm{~h}$. The solution contained in the dialysis tubing was then adjusted to $\mathrm{pH} 4.5$, with $1 \mathrm{M} \mathrm{HCl}$ solution (2-3 drops). A colourless precipitate was observed, and after the addition of acetone $(100 \mu \mathrm{L})$ and sodium chloride $(2 \mathrm{mg})$, the mixture was centrifuged $(3600 \times g$ for $20 \mathrm{~min})$. The supernatant was removed and the precipitate resuspended in distilled water. Acetone $(100 \mu \mathrm{L})$ plus solid sodium chloride $(2 \mathrm{mg})$ were added and the centrifugation process repeated twice. The precipitate obtained was redissolved in water $(2.0 \mathrm{~mL})$ by the addition of a minimal quantity of saturated sodium hydrogencarbonate solution. The resulting clear solution was lyophilised to give $\mathbf{2 4 - 2 6}$, as a colourless powder.

2.1.2.16. Human serum albumin-conjugate (24). NHydroxysuccinimide ester derivative 18 (22 mg, $0.05 \mathrm{mmol})$ was treated by the general procedure to afford the conjugate 24 (44 mg), as a colourless powder.

2.1.2.17. Human serum albumin-conjugate (25). $\mathrm{N}$ Hydroxysuccinimide ester derivative 19 (15 mg, $0.04 \mathrm{mmol}$ ) was treated by the general procedure to afford the conjugate 25 (55 mg), as a colourless powder.

2.1.2.18. Human serum albumin-conjugate (26). $\mathrm{N}$ Hydroxysuccinimide ester $20(0.023 \mathrm{~g}, 0.048 \mathrm{mmol})$ was treated as per the general procedure to give 26a, as a colourless powder $(42 \mathrm{mg})$. Lyophilisation of the combined supernatants from the centrifugation afforded $\mathbf{2 6 b}(12 \mathrm{mg})$, as a colourless powder.

\subsubsection{Determination of steroid/HSA molar ratio}

The extinction coefficient $(\varepsilon)$ for $17 \alpha$-methyltestosterone (carboxymethyl)oxime (17) was calculated from UV absorbance measurements at $\lambda_{\max } 254 \mathrm{~nm}$. The blank solution consisted of $10 \% \mathrm{EtOH} / 0.1 \mathrm{M} \mathrm{pH} 7.5$ buffer solution. Concentrations of compound 17 of $1.27 \times 10^{-4}$, $6.34 \times 10^{-5}, 3.17 \times 10^{-5}$ and $1.27 \times 10^{-5} \mathrm{~mol} \mathrm{~L}^{-1}$ in $10 \%$ EtOH/0.1 M pH 7.5 buffer solutions were employed and absorbances at $\lambda_{\max } 254$ were measured as 1.952, 1.023, 0.5717 and 0.2295 , respectively. From a plot of absorbance versus concentration, $\varepsilon$ for compound $\mathbf{1 7}$ was determined to be $15,680 \mathrm{~L} \mathrm{~mol}^{-1}$. Steroid/HSA molar ratio calculations assumed that $\varepsilon$ (compound 17) $=\varepsilon$ (conjugated steroids). 
Table 1

Molar ratios (steroid/HSA) determined by UV analyses at $254 \mathrm{~nm}$

\begin{tabular}{ll}
\hline Conjugate & Molar ratio (steroid-HSA) \\
\hline $\mathbf{2 3 a}$ & 12 \\
$\mathbf{2 3 b}$ & 9 \\
$\mathbf{2 6 a}$ & 28 \\
$\mathbf{2 6 b}$ & N.D. \\
\hline
\end{tabular}

For the determination of the steroid/HSA molar ratio, UV absorbances were measured at $\lambda 254 \mathrm{~nm}$. The blank consisted of $0.1 \mathrm{M} \mathrm{pH} 7.5$ buffer solution. Absorbances at $\lambda 254 \mathrm{~nm}$ were determined for dialysed HSA and conjugates 23a, 23b, 26a and 26b as $0.1 \mathrm{M}$ pH 7.5 buffer solutions, each at a concentration of $1.0 \times 10^{-6} \mathrm{M}$ in $50 \mathrm{~mL}$ (the molecular weight of the conjugates was assumed to be $76,101 \mathrm{~g} \mathrm{~mol}^{-1}$ ). The contribution to the absorbance at $254 \mathrm{~nm}$ of the steroid residues in each of the conjugates was obtained by subtracting the absorbance of HSA (at $254 \mathrm{~nm}$ ) from that of the conjugates. The molar ratio was then determined using the method of calculation described by Erlanger et al. [36] and using a molecular weight of HSA of $66,462 \mathrm{~g} \mathrm{~mol}^{-1}$. In the case of $\mathbf{2 6 \mathbf { b }}$, much lower absorbances at $\lambda 208 \mathrm{~nm}\left(\lambda_{\max }\right.$ of HSA) and $\lambda 254 \mathrm{~nm}$ were obtained, and so the molar ratio was not determined for this fraction. The molar ratios for 23a, 23b and $\mathbf{2 6 a}$ are presented in Table 1.

\subsection{Production of polyclonal antibodies}

All procedures that involved the use of animals were conducted in accordance with the Australian Code of Practice for the Care and Use of Animals for Scientific Purposes (National Health and Medical Research Council, 1997, Australian Government Publishing Services, Canberra, ACT), and were approved by the Animal Care and Ethics Committee of Charles Sturt University.

Sixteen Merino wether lambs $(35-45 \mathrm{~kg})$ were purchased from a commercial breeder and transported to Charles Sturt University, Wagga Wagga, where they were kept on pasture with ad libitum access to feed and water. Individual sheep were identified by fitting ear tags and were treated for internal parasites using ivermectin. On the first day of vaccination, a $10 \mathrm{~mL}$ blood sample was collected from each animal by jugular venipuncture. Then, each lamb was given a subcutaneous injection of $2 \mathrm{~mL}$ of vaccine, divided over four sites around the neck and shoulders to minimise the severity of any site reaction. The vaccine comprised steroid-HSA conjugate 21, 22, 24 or $25(500 \mu \mathrm{g})$ dissolved in sterile isotonic saline $(1 \mathrm{~mL})$, and emulsified with Freund's complete adjuvant $(1 \mathrm{~mL})$ (Sigma Chemical, St. Louis MO, US). Each of the four steroid conjugates $\mathbf{2 1}, \mathbf{2 2}, \mathbf{2 4}$ and $\mathbf{2 5}$ were administered to four lambs.

Twenty-eight and 56 days after the primary vaccination, the sheep each received a $2 \mathrm{~mL}$ booster vaccination containing steroid-HSA conjugate 21, 22, 24 or $\mathbf{2 5}(500 \mu \mathrm{g})$ emulsified with Freund's incomplete adjuvant (1 mL) (Sigma Chem- ical, St. Louis MO, US). On day 87, the sheep were exsanguinated, the blood was centrifuged $(3000 \times g$ for $20 \mathrm{~min})$, and the serum stored frozen at $-20^{\circ} \mathrm{C}$, until the determination of sera antibody titres (Section 2.3.3) and cross-reactivity (Section 2.3.4) by ELISA. Sera were then transported from Wagga Wagga to Sydney, and stored at $4{ }^{\circ} \mathrm{C}$.

\subsection{Biochemistry}

\subsubsection{Chemicals and reagents}

The following buffers were used in the assay: carbonate coating buffer $(0.1 \mathrm{M}, \mathrm{pH}$ 9.6), sodium carbonate $(0.795 \mathrm{~g})$, sodium hydrogencarbonate $(1.46 \mathrm{~g})$, distilled water $(500 \mathrm{~mL})$; wash buffer, sodium chloride $(17 \mathrm{~g})$, Tween $20(1.1 \mathrm{~g})$, distilled water $(2.0 \mathrm{~L})$; assay buffer, phosphate buffered saline tablets (two tablets), Tween $20(0.22 \mathrm{~g})$, distilled water $(400 \mathrm{~mL})$ and stop solution $\left(0.2 \mathrm{M} \mathrm{H}_{2} \mathrm{SO}_{4}\right)$.

All buffers used Milli Q Water except the wash buffer, which used Milli Ro; sodium carbonate (anhydrous) and sodium bicarbonate powders were obtained from Mallinckrodt Speciality Chemicals; sodium chloride was obtained from Selby-Biolab; and polyoxyethylenesorbitan monolaurate (Tween 20), phosphate buffered saline tablets, donkey anti-sheep $\operatorname{IgG}$ (whole molecule) peroxidase conjugate (antibody 2) and ovalbumin were from Sigma-Aldrich (Castle Hill, NSW, Australia). Liquid substrate for horseradish peroxidase (HRP), 3,3',5,5'-tetramethylbenzidine (TMB), was from TCC. Microtitre plates were clear, non-sterile, flat-bottomed plates with 96 wells from both Greiner Bio-one and ICN Biomedicals. An Helix pomatia $\beta$-glucuronidase preparation from Biozyme Laboratories was employed, $\mathrm{P} / \mathrm{N}$ GH2G, $8.977 \times 10^{6}$ units per $100 \mathrm{~mL}$. Anhydrous methanolic $\mathrm{HCl}(1 \mathrm{M})$ was prepared according to the method of Tang and Crone [37]. Methandriol (17 $\alpha$-methylandrost-

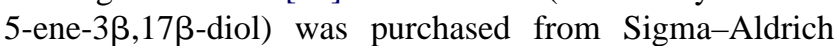
(Castle Hill, NSW, Australia). The preparation of 19-nor$5 \alpha, 17 \alpha$-pregnane-3 $\beta, 17 \beta$-diol (GCMS internal standard) has been described previously [22].

\subsubsection{Instrumentation}

Abselut Nexus solid-phase extraction (SPE) cartridges (30 mg, $1 \mathrm{~mL}$ ) were obtained from Varian (Mulgrave, VIC., Australia); Oasis MCX SPE cartridges $(30 \mathrm{mg}, 1 \mathrm{~mL})$ were from Waters (Rydalmere, NSW, Australia). Solid-phase extractions were automated using a Gilson (Villiers-le-Bel, France) Aspec XL4 liquid-handling system. ELISA work employed a Bio-Tek Instruments (Winooski, VT, USA). Model ELP 35 microplate washer and a Sorin Biomedica (Saluggia, Italy) Eti-System microplate reader. Absorbances were measured at the dual wavelengths of 450 and $620 \mathrm{~nm}$. GCMS data were obtained in EI mode on a Shimadzu QP-5000 instrument equipped with an AS-1400 autosampler. The column was a SGE BPX-5 capillary column $(12 \mathrm{~m} \times 0.22 \mathrm{~mm}$ i.d., $0.33 \mu \mathrm{m}$ film thickness) with helium as carrier gas. 


\subsubsection{Determination of antibody titres by ELISA to optimise sera concentrations}

2.3.3.1. Conjugation of antigens and immobilisation (plate coating). To carboxylic acids $\mathbf{1 5}$ or $\mathbf{1 6}(20 \mathrm{mg})$ in 1,4-dioxane $(2.5 \mathrm{~mL})$ was added a solution of EDC $(10 \mathrm{mg})$ in deionised water $(1 \mathrm{~mL})$. After stirring for $30 \mathrm{~min}$, a solution of ovalbumin $(30 \mathrm{mg})$ in $\mathrm{pH} 7.5$ sodium phosphate buffer $(0.1 \mathrm{M}$, $4 \mathrm{~mL}$ ) was added and the reaction mixture was stirred for $20 \mathrm{~h}$. A further quantity of EDC $(5 \mathrm{mg})$ was then added and the reaction was stirred for $4 \mathrm{~h}$. The reaction mixture was transferred to dialysis tubing and dialysed against stirred, deionised water for 3 days. The contents of the dialysis sack were centrifuged to remove a colourless precipitate, and the supernatant fraction was lyophilised to give ovalbumin conjugates of $\mathbf{1 5}(5.1 \mathrm{mg})$ or $\mathbf{1 6}(4.1 \mathrm{mg})$.

Microtitre plate wells were coated with the appropriate antigen, either ovalbumin conjugated to $\mathbf{1 5}$ or $\mathbf{1 6}(0.5 \mu \mathrm{g}$, $\left.5 \mu \mathrm{g} \mathrm{mL}^{-1}\right)$, in $\mathrm{pH} 9.6$ carbonate coating buffer $(0.1 \mathrm{M}$, $100 \mu \mathrm{L}$ ) and incubated overnight at $4{ }^{\circ} \mathrm{C}$. The plates were then washed six times with wash buffer and tapped dry to give 16 $\beta$-hydroxymestanolone plates or mestanolone plates, respectively. Coated plates were either used immediately, or stored for up to two weeks at $4{ }^{\circ} \mathrm{C}$, wrapped in the presence of desiccant.

\subsubsection{Procedure for 16 $\beta$-hydroxymestanolone plates with} antisera produced against 21 and 24 and for mestanolone plates with antisera produced against 22 and 25. Antisera raised in the sheep against conjugates 21, 22, 24 or 25 were each diluted in assay buffer to the first appropriate level, then serially diluted, and $100 \mu \mathrm{L}$ of each dilution was placed in a separate well of a prepared plate (Section 2.3.3). The plate was then incubated at $37^{\circ} \mathrm{C}$ for $60 \mathrm{~min}$. The plate was then washed six times with wash buffer, and tapped dry. Antibody 2 (donkey anti-sheep conjugate) diluted (1/2500) in assay buffer $(100 \mu \mathrm{L})$ was then added to each well, and the plate was incubated at $37^{\circ} \mathrm{C}$ for $60 \mathrm{~min}$.

The plate was then washed six times with wash buffer and tapped dry. The HRP-TMB substrate $(100 \mu \mathrm{L})$ was added and incubated for $20 \mathrm{~min}$, at room temperature. Stop solution $\left(100 \mu \mathrm{L}, 0.2 \mathrm{M} \mathrm{H}_{2} \mathrm{SO}_{4}\right)$ was then added to each well, and the plate was read at the dual wavelengths of 450 and $620 \mathrm{~nm}$. Serum collected from each sheep on day 0 (before vaccination) was used to determine control absorbance levels. Non-specific binding was relatively low in this assay and so a blocking reagent was not necessary. Antibody titres were determined for day 87 antisera, and are listed in Table 2. The best antibody titres for each treatment were determined using an absorbance ( $B_{\text {DAY }} 87$ ) cut-off level of 0.2 absorbance units above the control absorbance $\left(B_{\text {DAY } 0}\right)$.

As determined with the $16 \beta$-hydroxymestanolone plate, sera from sheep vaccinated with conjugate $\mathbf{2 4}$ gave higher antibody titres than sera from sheep given conjugate $\mathbf{2 1}$. With the mestanolone plate, sera arising from treatment with vaccine containing conjugate $\mathbf{2 5}$ gave higher antibody titres than treatment with vaccine containing conjugate $\mathbf{2 2}$. For use in
Table 2

Antibody titres determined for four HSA conjugates 87 days after primary vaccination

\begin{tabular}{lll}
\hline Antigen & Sheep & Titre (in which $\left.B_{\text {DAY } 87}-B_{\text {DAY } 0} \geq 0.2\right)$ \\
\hline $\mathbf{2 1}$ & $\mathrm{A}_{21}$ & $1 / 204800$ \\
& $\mathrm{~B}_{21}$ & $1 / 204800$ \\
& $\mathrm{C}_{21}$ & $1 / 204800$ \\
& $\mathrm{D}_{21}$ & $1 / 204800$ \\
$\mathbf{2 2}$ & $\mathrm{A}_{22}$ & $1 / 51200$ \\
& $\mathrm{~B}_{22}$ & $1 / 25600$ \\
& $\mathrm{C}_{22}$ & $1 / 102400$ \\
$\mathbf{2 4}$ & $\mathrm{D}_{22}$ & $1 / 204800$ \\
& $\mathbf{A}_{24}$ & $\mathbf{1} / \mathbf{1 6 3 8 4 0 0}$ \\
& $\mathrm{B}_{24}$ & $1 / 1638400$ \\
& $\mathrm{C}_{24}$ & $1 / 819200$ \\
& $\mathrm{D}_{24}$ & $1 / 819200$ \\
$\mathbf{2 5}$ & $\mathrm{A}_{25}$ & $1 / 1638400$ \\
& $\mathbf{B}_{25}$ & $\mathbf{1 / 3 2 7 6 8 0 0}$ \\
& $\mathrm{C}_{25}$ & $1 / 1638400$ \\
& $\mathrm{D}_{25}$ & $1 / 1638400$ \\
\hline
\end{tabular}

the ELISA, the highest titre antisera produced against $\mathbf{2 4}$ (1/1638400, sheep $\left.A_{24}\right)$ and against 25 (1/3276800, sheep $\mathrm{B}_{25}$ ) were chosen and both were found to be adequate for use at a 1/819200 dilution in assay buffer.

\subsubsection{Determination of cross-reactivities by ELISA}

2.3.4.1. Procedure for 16 $\beta$-hydroxymestanolone plates with antisera produced against 24 and for mestanolone plates with antisera produced against 25. Anabolic steroid standards (refer to Tables 3 and 4) were prepared in assay buffer at a concentration of $100 \mathrm{ng} \mathrm{mL}^{-1}$, as well as $16 \beta$ hydroxymestanolone at 1.6, 3.2, 6.3, 12.5, 25, 50, 100 and $200 \mathrm{ng} \mathrm{mL}^{-1}$, and $50 \mu \mathrm{L}$ was added to each well, followed by $50 \mu \mathrm{L} 1 / 819200$ diluted sheep antiserum. The plate was then shaken, covered, and incubated at $37^{\circ} \mathrm{C}$ for $60 \mathrm{~min}$. The plate was then washed six times with wash buffer, and dried.

Antibody 2 (donkey anti-sheep conjugate) was then diluted $1 / 2500$ in assay buffer and $100 \mu \mathrm{L}$ was added to each well. The reagents were mixed by gently tapping the plate before it was wrapped and incubated at $37^{\circ} \mathrm{C}$ for $60 \mathrm{~min}$. The plate was then washed six times with wash buffer, tapped dry, and then the HRP-TMB substrate $(100 \mu \mathrm{L})$ was added and incubated for $20 \mathrm{~min}$, at room temperature. Next, stop solution $\left(100 \mu \mathrm{L}, 0.2 \mathrm{M} \mathrm{H}_{2} \mathrm{SO}_{4}\right)$ was added to each well, and the plates were read at the dual wavelengths of 450 and $620 \mathrm{~nm} . \mathrm{B} / \mathrm{B}_{\mathrm{o}} \%$ absorbances were then measured, and cross-reactivities were determined, as shown in Table 3 (16 $\beta$-hydroxymestanolone plates) and Table 4 (mestanolone plates).

2.3.4.2. Validity of the cross-reactivity studies. The $B / B_{0} \%$ absorbances for each ligand were determined by the same ELISA assay for a number of the cross-reactive anabolic steroid standards, at various concentrations, for comparison with the original steroid antigen, 16 $\beta$-hydroxymestanolone (for the 16 $\beta$-hydroxymestanolone plate) or mestanolone 
Table 3

Percentage cross-reactivities for anabolic steroids standards: $16 \beta-$ hydroxymestanolone plate with antibodies produced against human serum albumin-conjugate (24)

\begin{tabular}{|c|c|}
\hline Anabolic steroid standard & Cross-reactivity $(\%)$ \\
\hline $16 \beta$-Hydroxymestanolone & 100 \\
\hline $16 \beta$-Hydroxystanozolol & 100 \\
\hline $17 \alpha$-Methyl- $5 \alpha$-androstane- $3 \beta, 16 \beta, 17 \beta$-triol & 100 \\
\hline $\begin{array}{l}\text { 16 } \beta, 17 \beta \text {-Dihydroxy- } 17 \alpha \text {-methyl- } 5 \alpha \text {-androst-1- } \\
\text { en-3-one }\end{array}$ & 100 \\
\hline $16 \beta$-Hydroxymethandrostenolone & 84.3 \\
\hline $16 \alpha$-Hydroxyfurazabol & 39.8 \\
\hline 19-Nor-5 $\alpha, 17 \alpha$-pregnane- $3 \beta, 16 \beta, 17 \beta$-triol & 5.5 \\
\hline $17 \alpha$-Hydroxyprogesterone & 2.8 \\
\hline Norbolethane & 2.8 \\
\hline Furazabol & 2.4 \\
\hline $5 \alpha$-Estrane- $3 \beta, 17 \alpha$-diol & 2.4 \\
\hline $6 \beta$-Hydroxymethandrostenolone & 2.3 \\
\hline Stanolone & 2.2 \\
\hline Epitestosterone & 2.2 \\
\hline Trenbolone & 2.2 \\
\hline Ethylestrenol & 2.1 \\
\hline Tetrahydrogestrinone (THG) & 2.0 \\
\hline Fluoxymesterone & 2.0 \\
\hline Oxymetholone & 2.0 \\
\hline 3'-Hydroxystanozolol & 2.0 \\
\hline Boldenone & 1.8 \\
\hline Testosterone & 1.8 \\
\hline $5 \alpha$-Estrane- $3 \beta, 16 \alpha, 17 \beta$-triol & 1.8 \\
\hline $5 \alpha$-Estrane- $3 \beta, 16 \beta, 17 \beta$-triol & 1.8 \\
\hline $17 \alpha$-Methyl- $5 \alpha$-androstane- $3 \alpha, 17 \beta$-diol & 1.7 \\
\hline $17 \beta$-Estradiol & 1.6 \\
\hline Estrone & 1.6 \\
\hline Formebolone & 1.6 \\
\hline Epitrenbolone & 1.6 \\
\hline Ethinylestradiol & 1.6 \\
\hline Hydrocortisone & 1.6 \\
\hline Nandrolone & 1.5 \\
\hline Ethisterone & 1.5 \\
\hline Mibolerone & 1.4 \\
\hline Norpregnandiol & 1.4 \\
\hline Androsterone & 1.4 \\
\hline Bolasterone & 1.3 \\
\hline $17 \alpha$-Estradiol & 1.3 \\
\hline Altrenogest & 1.3 \\
\hline Progesterone & 1.2 \\
\hline Methyltestosterone & 1.2 \\
\hline $17 \alpha$-Methyl- $5 \alpha$-androstane- $3 \beta, 17 \beta$-diol & 1.2 \\
\hline Normethandrone & 1.2 \\
\hline Mestanolone & 1.2 \\
\hline Methandriol & 1.1 \\
\hline $4 \alpha$-Hydroxystanozolol & 1.1 \\
\hline Danazol & 1.1 \\
\hline Oxymesterone & 1.1 \\
\hline $17 \alpha$-Methyl- $5 \alpha$-androstane- $3 \beta, 16 \alpha, 17 \beta$-triol & 1.1 \\
\hline Oxandrolone & 1.1 \\
\hline Dehydroandrosterone & 1.0 \\
\hline $4 \beta$-Hydroxystanozolol & $<1$ \\
\hline Methandrostenolone & $<1$ \\
\hline Stanozolol & $<1$ \\
\hline 19-Nor-5 $\alpha, 17 \alpha$-pregnane- $3 \beta, 16 \alpha, 17 \beta$-triol & $<1$ \\
\hline Norethandrolone & $<1$ \\
\hline
\end{tabular}

Table 4

Percentage cross-reactivities for anabolic steroids standards: mestanolone plate with antibodies produced against human serum albumin-conjugate (25)

\begin{tabular}{|c|c|}
\hline Anabolic steroid standard & Cross-reactivity $(\%)$ \\
\hline Mestanolone & 100 \\
\hline Methyltestosterone & 100 \\
\hline $17 \alpha$-Methyl-5 $\alpha$-androstane- $3 \beta, 17 \beta$-diol & 100 \\
\hline Methandriol & 78.7 \\
\hline Oxymetholone & 60.3 \\
\hline Oxymesterone & 41.8 \\
\hline Furazabol & 39.3 \\
\hline Stanozolol & 39.3 \\
\hline Ethisterone & 34.4 \\
\hline Oxandrolone & 33.5 \\
\hline Normethandrone & 29.9 \\
\hline Methandrostanolone & 28.1 \\
\hline $17 \alpha$-Methyl- $5 \alpha$-androstane- $3 \alpha, 17 \beta$-diol & 27.8 \\
\hline $4 \alpha$-Hydroxystanozolol & 26.2 \\
\hline Bolasterone & 25.2 \\
\hline Mibolerone & 24.9 \\
\hline $4 \beta$-Hydroxystanozolol & 23.2 \\
\hline 3'-Hydroxystanozolol & 17.1 \\
\hline Danazol & 16.5 \\
\hline Norpregnandiol & 9.1 \\
\hline Ethinylestradiol & 9.1 \\
\hline Norethandrolone & 8.4 \\
\hline Stanolone & 6.3 \\
\hline Testosterone & 5.6 \\
\hline $17 \alpha$-Methyl-5 $\alpha$-androstane- $3 \beta, 16 \beta, 17 \beta$-triol & 5.6 \\
\hline $16 \beta$-Hydroxymestanolone & 5.4 \\
\hline Norbolethane & 4.9 \\
\hline $16 \beta$-Hydroxystanozolol & 4.7 \\
\hline Tetrahydrogestrinone (THG) & 4.1 \\
\hline 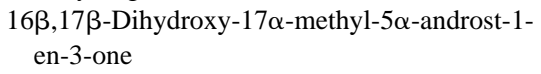 & 3.3 \\
\hline $16 \beta$-Hydroxymethandrenone & 3.0 \\
\hline $16 \alpha$-Hydroxyfurazabol & 2.8 \\
\hline $6 \beta$-Hydroxymethandrostanolone & 1.9 \\
\hline Dehydroandrosterone & 1.8 \\
\hline 19-Nor-5 $\alpha, 17 \alpha$-pregnane-3 $\beta, 16 \alpha, 17 \beta$-triol & 1.7 \\
\hline Nandrolone & 1.6 \\
\hline Fluoxymesterone & 1.3 \\
\hline Androsterone & 1.3 \\
\hline Boldenone & 1.2 \\
\hline Ethylestrenol & 1.1 \\
\hline Progesterone & $<1$ \\
\hline Altrenogest & $<1$ \\
\hline Trenbolone & $<1$ \\
\hline $17 \alpha$-Methyl- $5 \alpha$-androstane- $3 \beta, 16 \alpha, 17 \beta$-triol & $<1$ \\
\hline 19-Nor-5 $\alpha, 17 \alpha$-pregnane-3 $\beta, 16 \beta, 17 \beta$-triol & $<1$ \\
\hline $17 \beta$-Estradiol & $<1$ \\
\hline $17 \alpha$-Estradiol & $<1$ \\
\hline Estrone & $<1$ \\
\hline Epitestosterone & $<1$ \\
\hline Formebelone & $<1$ \\
\hline Epitrenbolone & $<1$ \\
\hline $17 \alpha$-Hydroxyprogesterone & $<1$ \\
\hline Hydrocortisone & $<1$ \\
\hline $5 \alpha$-Estrane- $3 \beta, 17 \alpha$-diol & $<1$ \\
\hline $5 \alpha$-Estrane- $3 \beta, 16 \alpha, 17 \beta$-triol & $<1$ \\
\hline
\end{tabular}




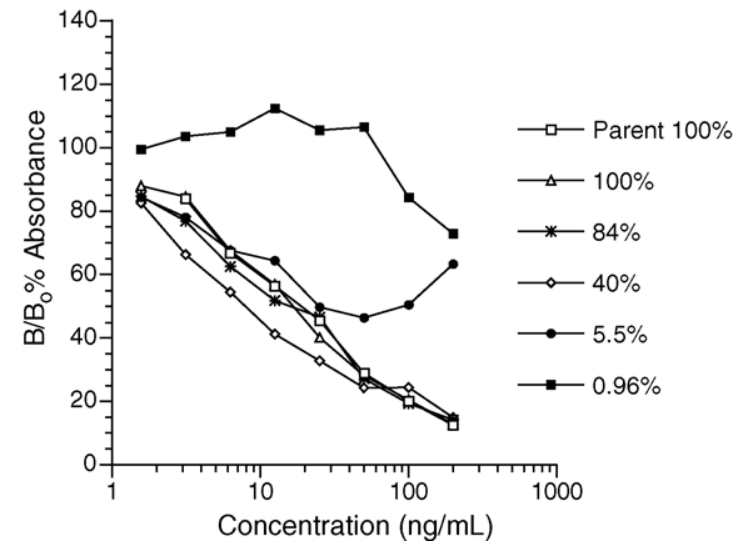

Fig. 4. Validation of the cross-reactivity comparisons: parallelism of various cross-reacting steroid ligands on the $16 \beta$-hydroxymestanolone plate. [Parent compound is 16 $\beta$-hydroxymestanolone (9). 100\% $=16 \beta$ hydroxystanozolol, $\quad 84 \%=16 \beta$-hydroxymethandrenone, $\quad 40 \%=16 \alpha$ hydroxyfurazabol, $5.5 \%=19$-nor-5 $\alpha, 17 \beta$-pregnane- $3 \beta, 16 \beta, 17 \beta$-triol and $0.963 \%=$ stanozolol].

(for the mestanolone plate). Plots of percentage absorbance $\left(B / B_{0} \%\right)$ versus concentration were constructed, as shown in Figs. 4 and 5. The parallel nature of these plots, relative to the original steroid, validates the cross-reactivity comparisons, which imply that cross-reactive steroids bind to the antibodies with similar affinities.

\subsubsection{Equine administration}

Both animal administration trials were approved by the New South Wales Thoroughbred Racing Board Animal Care and Ethics Committee.

An aqueous suspension of stanozolol (4) $\left(\mathrm{Stanazol}^{\circledR}\right.$, RWR Veterinary Products, Glenorie, NSW, Australia; $5 \mathrm{~mL}=250 \mathrm{mg}$ stanozolol) was administered to a thoroughbred gelding ( 7 years; $580 \mathrm{~kg}$ ) by intramuscular injection. Urine samples were collected daily, for 28 days, by con-

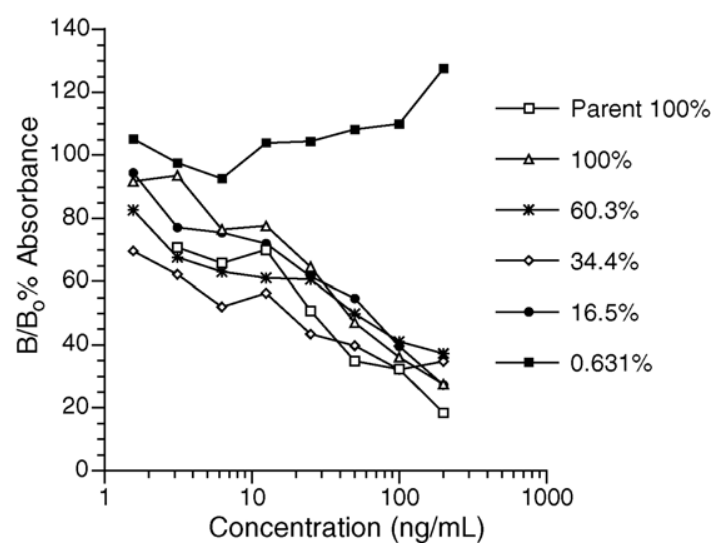

Fig. 5. Validation of the cross-reactivity comparisons: parallelism of various cross-reacting steroid ligands on the mestanolone plate. [Parent compound is mestanolone $(\mathbf{1 0})$. $100 \%=$ methandriol, $60.3 \%=$ oxymetholone, $34.4 \%=$ ethisterone, $16.5 \%=$ danazol and $0.631 \%=$ estrone $]$. ditioned spontaneous voiding and immediately frozen and stored at $-20^{\circ} \mathrm{C}$ until required for analysis.

An oil-based solution of methandriol dipropionate (Protabol ${ }^{\circledR}$, RWR Veterinary Products, Glenorie, NSW, Australia; $5 \mathrm{~mL}=375 \mathrm{mg}$ methandriol dipropionate) was administered to a standardbred gelding (aged; $560 \mathrm{~kg}$ ) by intramuscular injection. Urine samples were collected daily, for 28 days, by conditioned spontaneous voiding and immediately frozen and stored at $-20^{\circ} \mathrm{C}$ until required for analysis.

\subsubsection{ELISA development: application to post-administration equine urine samples}

2.3.6.1. Analysis of 16 3 -hydroxymestanolone assay with equine urine following stanozolol (4) administration. ELISA plates were prepared as in Section 2.3.3 and the assay was performed, as per the method described in Section 2.3.4, using $50 \mu \mathrm{L}$ of test sample per well. The $1.6 \mathrm{ng} \mathrm{mL}^{-1} 16 \beta$ hydroxymestanolone standard showed clearly suppressed binding compared to a reagent blank. All administration samples were analysed with this procedure, varying the standards, antibodies and plates as appropriate.

Negative results (lack of detectable suppression of bindings) were obtained with raw post-administration urine samples using the $16 \beta$-hydroxymestanolone assay. Raw urine was hydrolysed overnight at $37^{\circ} \mathrm{C}$ with $1 / 100$ dilution of $\beta$-glucuronidase, and examined by the $16 \beta$ hydroxymestanolone assay. The suppressed absorbance values obtained in the assay, relative to the negative control, are shown in the excretion curve in Fig. 6(a).

Alternatively, raw urine $(1 \mathrm{~mL})$ was treated by extraction on a Gilson Aspec XL4 liquid-handling system. The urine was adjusted to $\mathrm{pH} 5$ and loaded onto an unconditioned reverse-phase SPE cartridge ( $30 \mathrm{mg}, 1 \mathrm{~mL}$, Abselut Nexus). The cartridge was washed with sodium hydroxide solution $(0.1 \mathrm{M})$ and water and then eluted with methanol. The extract was evaporated to dryness at $70^{\circ} \mathrm{C}$, under a stream of $\mathrm{N}_{2}$. Anhydrous $1 \mathrm{M} \mathrm{HCl} / \mathrm{methanol}(0.5 \mathrm{~mL})$ was added and the mixture were incubated at $60^{\circ} \mathrm{C}$ for $10 \mathrm{~min}$. The solvolysate was then quenched with $2 \mathrm{~mL}$ of $0.25 \mathrm{M}$ $\mathrm{pH} 8$ phosphate buffer. Fifty microlitres of this quenched methanolysed extract (solvolysate) was analysed by the $16 \beta$ hydroxymestanolone ELISA. The suppressed absorbances, relative to the negative control, are shown in the excretion curve in Fig. 6(b). The remainder of the quenched solvolysate was loaded onto an unconditioned mixed-mode (reversephase/cation exchange) SPE cartridge $(30 \mathrm{mg}, 1 \mathrm{~mL}$, Oasis MCX) and washed with sodium hydroxide solution $(0.1 \mathrm{M})$, then $\mathrm{HCl}$ solution $(0.1 \mathrm{M})$ and then water. Neutral steroids were eluted with ethyl acetate (neutral eluate). After a methanol wash, basic steroids were eluted with diethylamine/ ethyl acetate $(2 \%, \mathrm{v} / \mathrm{v})$. The basic eluate was dried at $70^{\circ} \mathrm{C}$ under a stream of $\mathrm{N}_{2}$. The residue was reconstituted in phosphate buffered saline $(200 \mu \mathrm{L})$ and $50 \mu \mathrm{L}$ was analysed using the 16 3 -hydroxymestanolone assay. The suppressed absorbance values obtained are depicted in the excretion curve in Fig. 6(c). 


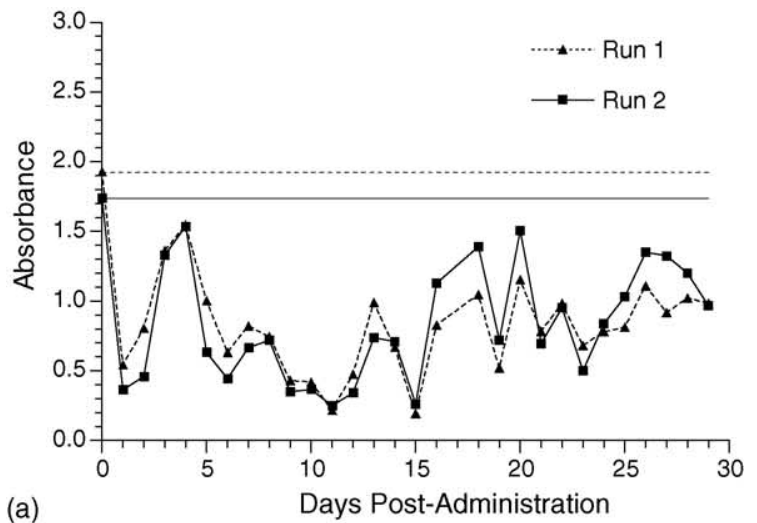

(a)
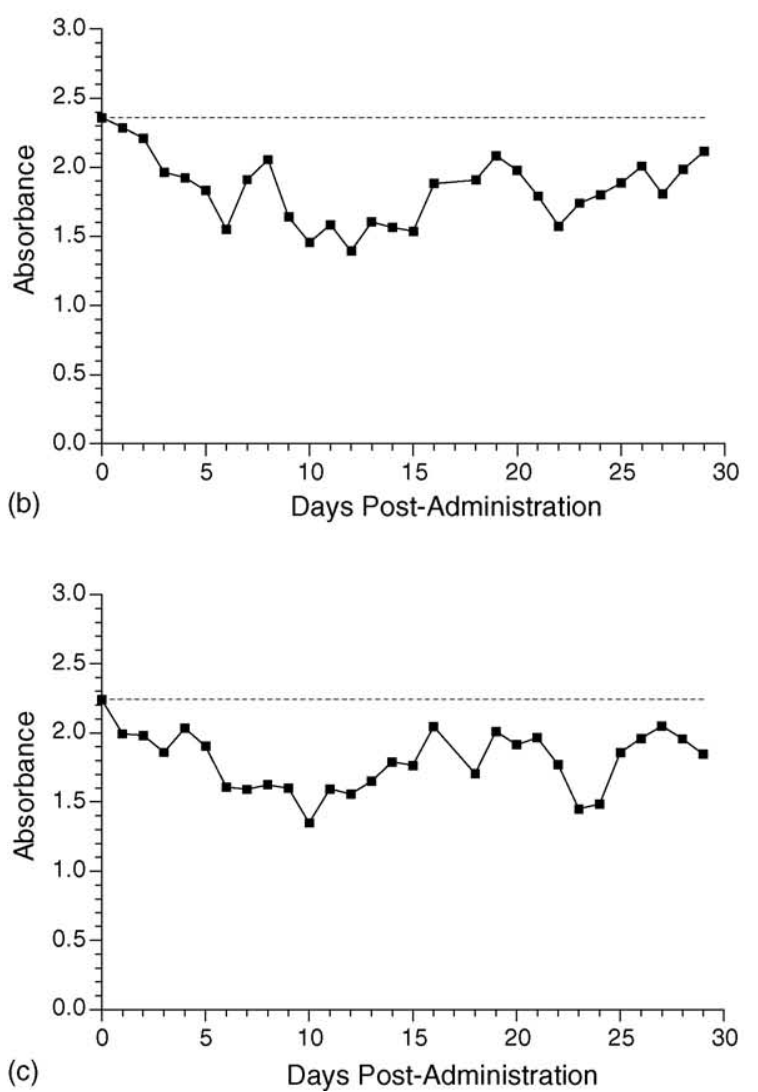

Fig. 6. Excretion curves, determined using the 16 $\beta$-hydroxymestanolone ELISA plate, detecting stanozolol metabolites in equine urine, as shown by the absorbance suppression relative to the negative control. Following the intramuscular injection of $250 \mathrm{mg}$ of stanozolol, the analyses were performed on urine which was: (a) hydrolysed with $\beta$-glucuronidase (1/100 dilution), (b) subjected to reverse-phase SPE, methanolysed and quenched and (c) subjected to mixed-mode SPE to give a basic eluate.

2.3.6.2. Analysis of mestanolone assay with equine urine following methandriol (27) administration. Raw urine and hydrolysed urine did not show significant suppression of absorbance in this assay. However, urine treated via reversephase SPE and subsequently methanolysed and quenched (as described for stanozolol) showed suppressed absorbances relative to the negative control (see Fig. 7(a)). Further treatment of the urine by mixed-mode SPE gave neutral eluates (as
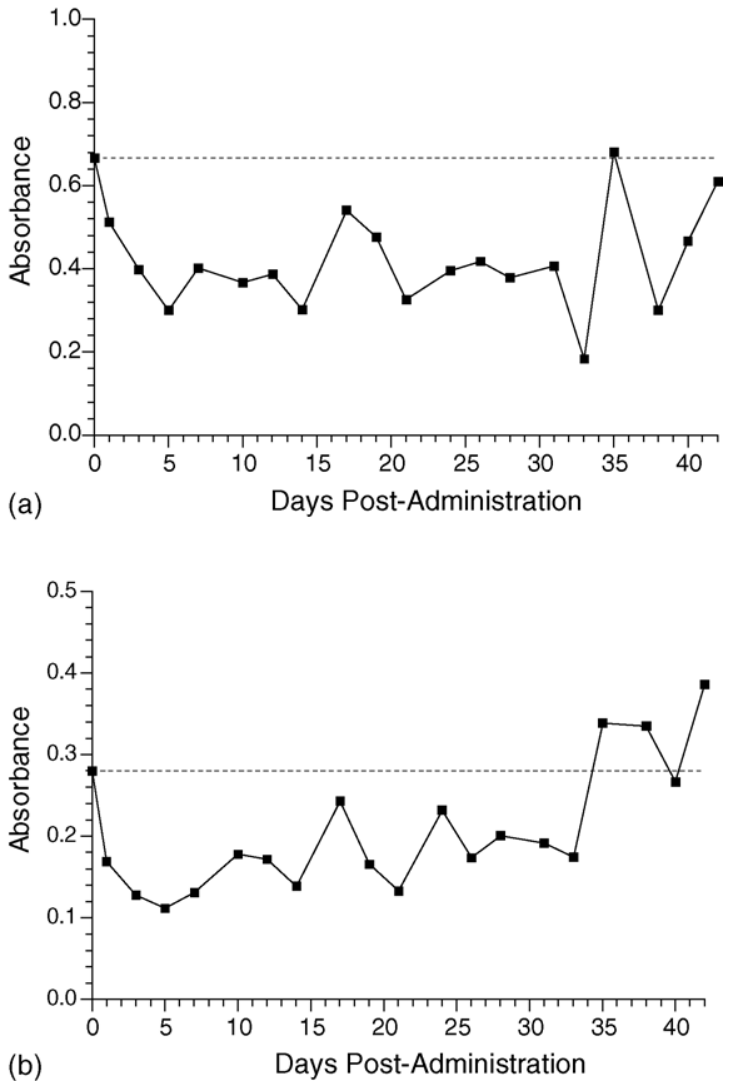

Fig. 7. Excretion curves, determined using the mestanolone ELISA plate, detecting methandriol metabolites in equine urine, as shown by the absorbance suppression relative to the negative control. Following the intramuscular injection of $375 \mathrm{mg}$ of methandriol dipropionate, the analyses were performed on urine which was (a) subjected to reverse-phase SPE, then methanolysed and quenched and (b) treated via mixed-mode SPE to give a neutral eluate.

for stanozolol), which gave suppressed absorbance measurements, relative to the negative control, in the excretion curve (see Fig. 7(b)).

2.3.6.3. Analysis of 16ß-hydroxymestanolone assay with equine urine following methandriol (27) administration. Methanolysed/quenched reverse-phase SPE treated urine and neutral eluates subsequently obtained after mixed-mode SPE (as described for stanozolol) gave suppressed absorbance measurements, as shown in Fig. 8.

\subsubsection{GCMS analysis of equine urine following methandriol (27) administration}

2.3.7.1. Sample preparation. Duplicate aliquots of urine $(3 \mathrm{~mL})$ were adjusted to $\mathrm{pH} 7$ and spiked with 19 -nor- $5 \alpha, 17 \alpha$ pregnane-3 $\beta, 17 \beta$-diol $\left(20 \mathrm{ng} \mathrm{mL}^{-1}\right)$ as an internal standard. The samples were centrifuged $(2000 \times g$, for $5 \mathrm{~min})$ to sediment particulate matter, after which the supernatant fractions were loaded onto unconditioned Abselut Nexus solid-phase extraction cartridges $(60 \mathrm{mg}, 3 \mathrm{~mL})$. The cartridges were rinsed with sodium hydroxide solution $(0.1 \mathrm{M}, 2 \mathrm{~mL})$ and water $(2 \mathrm{~mL})$, and then dried briefly with air. The steroids 

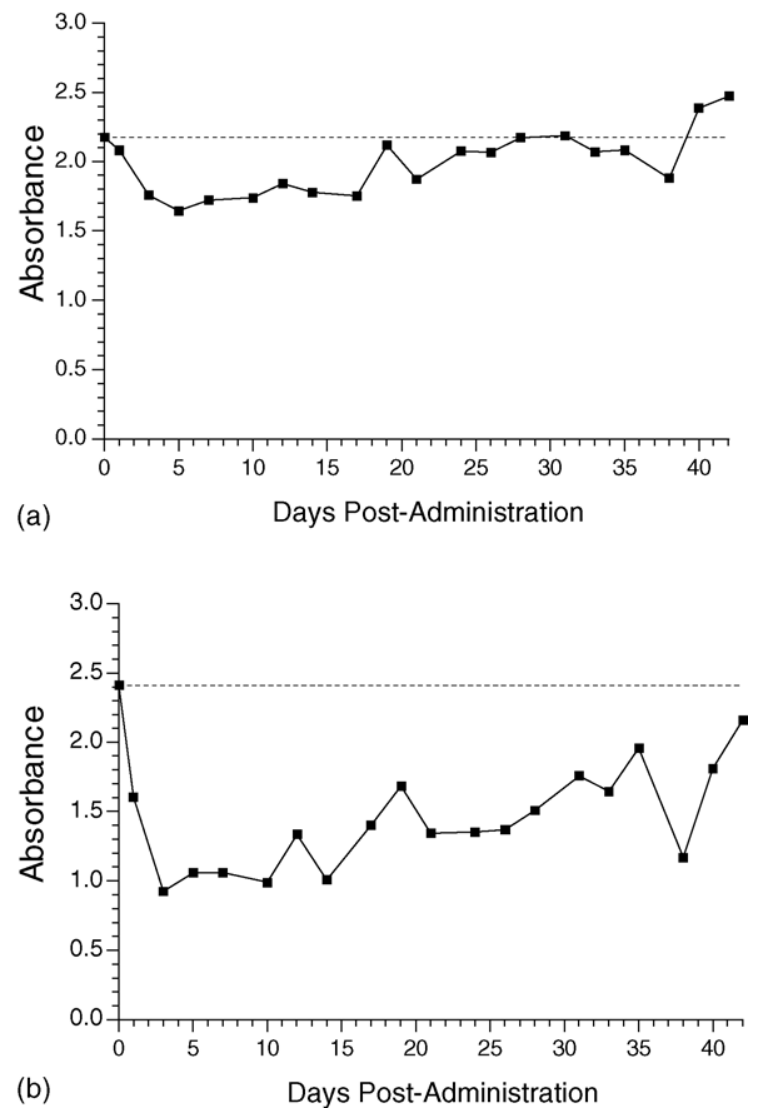

Fig. 8. Excretion curves, determined using a $16 \beta$-hydroxymestanolone ELISA plate, detecting methandriol metabolites in equine urine, as shown by the absorbance suppression relative to the negative control. Following the intramuscular injection of $375 \mathrm{mg}$ of methandriol dipropionate, the analyses were performed on urine which was (a) subjected to reverse-phase SPE, then methanolysed and quenched and (b) treated via mixed-mode SPE to give a neutral eluate.

were eluted with methanol $(2 \mathrm{~mL})$ and dried, by evaporation at $80^{\circ} \mathrm{C}$, under a stream of nitrogen. Steroidal sulfate and $\beta$-glucuronide conjugates were cleaved by reconstituting in anhydrous methanolic $\mathrm{HCl}(1 \mathrm{M}, 0.5 \mathrm{~mL})$ and incubating for $10 \mathrm{~min}$ at $60^{\circ} \mathrm{C}$. The reaction was quenched by the addition of sodium hydroxide solution $(2 \mathrm{M}, 4 \mathrm{~mL})$ and extracted with diisopropyl ether $(4 \mathrm{~mL})$. The organic extracts were dried by evaporation at $80^{\circ} \mathrm{C}$, under a stream of nitrogen. The residues were reconstituted in acetonitrile $(80 \mu \mathrm{L})$ and pentafluoropropionic anhydride $(20 \mu \mathrm{L})$ and incubated for $15 \mathrm{~min}$ at $60^{\circ} \mathrm{C}$, and then dried, by evaporation at $80^{\circ} \mathrm{C}$, under a stream of nitrogen. The derivatised residues were reconstituted in ethyl acetate $(50 \mu \mathrm{L})$ for GCMS analysis.

2.3.7.2. GCMS analysis. Sample injections were made in split/splitless mode with an injector temperature of $250^{\circ} \mathrm{C}$. The column was initially held at $100^{\circ} \mathrm{C}$ for $1 \mathrm{~min}$, then ramped at $25-300^{\circ} \mathrm{C} \mathrm{min}^{-1}$ and held for a further $1 \mathrm{~min}$. Head pressure was programmed to maintain a constant flow rate of $0.5 \mathrm{~mL} \mathrm{~min}^{-1}$ and the purge valve remained off for 1 min before opening to a split of 50:1. The MS transfer line

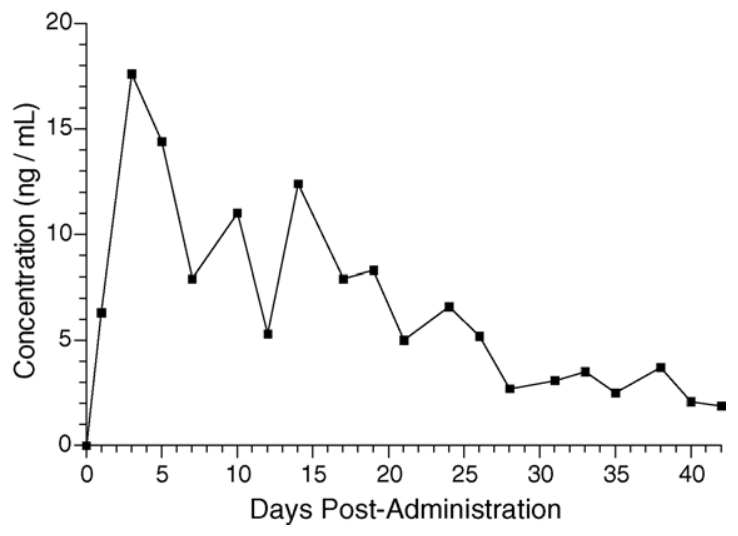

Fig. 9. Excretion curve, determined by GCMS analysis, for methandriol in equine urine following the intramuscular injection of $375 \mathrm{mg}$ of methandriol dipropionate. The analysis was performed on urine subjected to reversephase SPE, methanolysis and quenching, followed by derivatisation with pentafluoropropionic anhydride.

was set at $280^{\circ} \mathrm{C}$ and ionisation energy at $70 \mathrm{eV}$. Data were acquired in selected ion monitoring (SIM) mode, monitoring the ions $\mathrm{m} / \mathrm{z} 417$ for methandriol and $\mathrm{m} / \mathrm{z}, 405$ for 19nor- $5 \alpha, 17 \alpha$-pregnane- $3 \beta, 17 \beta$-diol (internal standard). The excretion curve obtained for methandriol (27) is shown in Fig. 9.

2.3.7.3. Quantitation. A duplicate calibration curve was constructed in blank equine urine over the range $0-40 \mathrm{ng} \mathrm{mL}^{-1}$. The curve was linear over the stated range with a correlation coefficient $\left(R^{2}\right)$ of 0.990 . Duplicate quality control spikes at $20 \mathrm{ng} \mathrm{mL}^{-1}$ returned concentration values within $5 \%$ of that expected. Further method validation was not performed.

\section{Results and discussion}

\subsection{Synthesis}

The aim of the synthetic studies was to diastereoselectively synthesise a representative 16,17-dihydroxy-17-alkyl anabolic steroid, and produce steroid-protein conjugates in order to raise antibodies that recognise the D-ring structure common to a number of steroid metabolites.

For this purpose, 16ß-hydroxymestanolone (9) was chosen as the representative steroid and was synthesised in six steps from commercially available epiandrosterone (12). As shown in Fig. 10, compound $\mathbf{1 3}$ was synthesised by published procedures [29-31]. Acetonide deprotection of $\mathbf{1 3}$ to yield $\mathbf{9}$ was achieved best using a Dowex $50 \mathrm{~W}-\mathrm{X} 8$ ion-exchange resin in methanol/water. Under these conditions, epimerisation of the $\mathrm{C} 17$ tertiary alcohol was minimised, such that a 14:1 ratio of 9 to 14 (17-epi-9) was obtained.

Thus, $16 \beta$-hydroxymestanolone (9), together with commercially available mestanolone (10) and $17 \alpha$-methyltestosterone (17 $\beta$-hydroxy-17 $\alpha$-methylandrost-4-en-3-one) 
<smiles>C[C@]12CCC3C(CC[C@@H]4C[C@H](O)CC[C@]34C)C1CCC2=O</smiles>

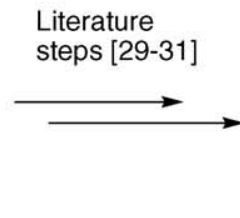<smiles>CC1(C)O[C@H]2CC3C4CC[C@H]5CC(=O)CC[C@]5(C)C4CC[C@]3(C)[C@]2(C)O1</smiles>

$70 \%$ Dowex $50 \mathrm{~W}-\mathrm{X} 8$ $\mathrm{MeOH}: \mathrm{H}_{2} \mathrm{O}(1: 1)$

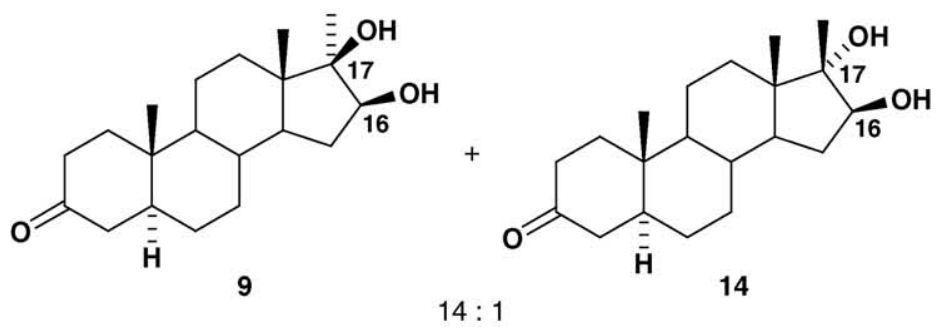

Fig. 10. Synthesis of 16ß-hydroxymestanolone (9).

(11), were available for conjugation to HSA, to produce the antigenic material. While the primary interest was to generate antibodies that specifically recognised the $16 \beta, 17 \beta-$ dihydroxy-17 $\alpha$-alkyl D-ring motif (see 9), antibodies were also raised against the parent steroidal $17 \beta$-hydroxy-17 $\alpha$ alkyl D-ring structure of $\mathbf{1 0}$ to enable a direct comparison of the selectivity of the antibodies formed. In addition, $17 \alpha-$ methyltestosterone (11) was conjugated to HSA to allow determination of the number of steroid residues attached per protein by UV spectroscopic methods. Optimisation of this ratio is important for the generation of antibodies specific for the steroid.

In order to link the steroids to HSA at a distal position to the D-ring, a carboxymethyloxime tether to the A-ring via the 3 -keto groups was chosen. Each of $16 \beta$-hydroxymestanolone (9), mestanolone (10) and $17 \alpha$-methyltestosterone (11) was converted to the corresponding oximes $\mathbf{1 5 - 1 7}$ by reaction with carboxymethoxylamine hemihydrochloride (Fig. 11).

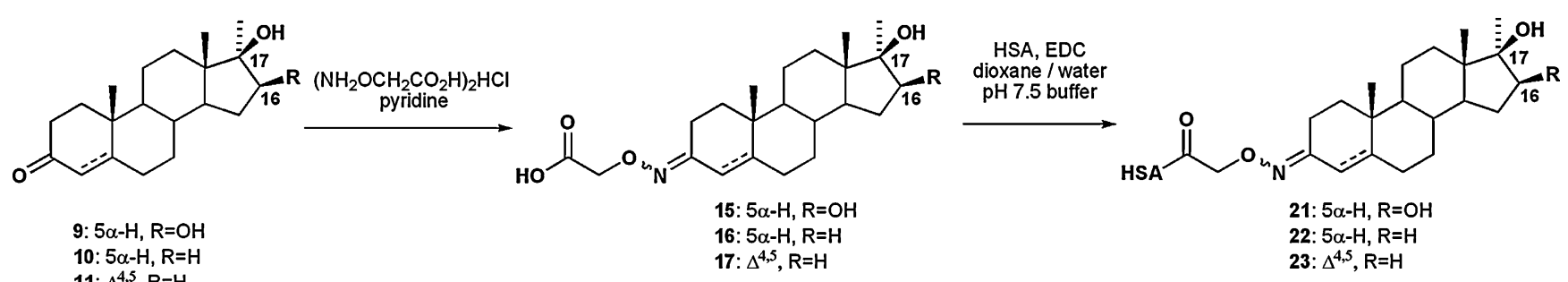

$11: \triangle \Delta^{4.5}, R=H$

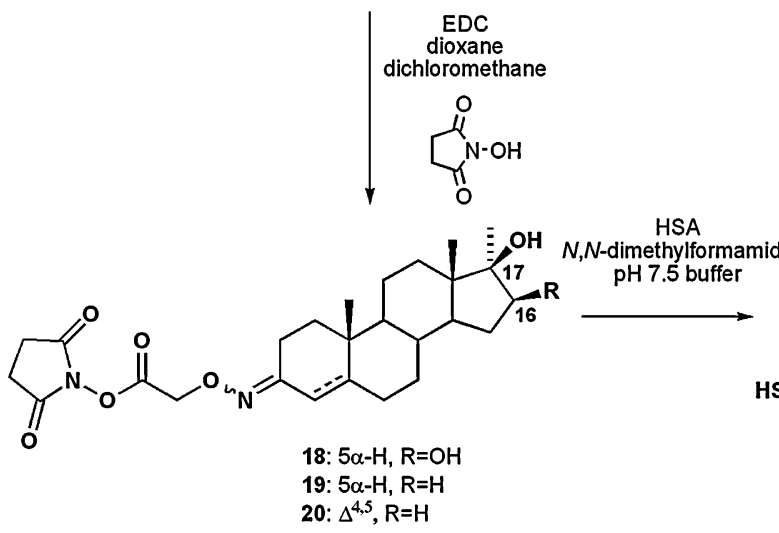

Carboxylic acid/EDC derived conjugates

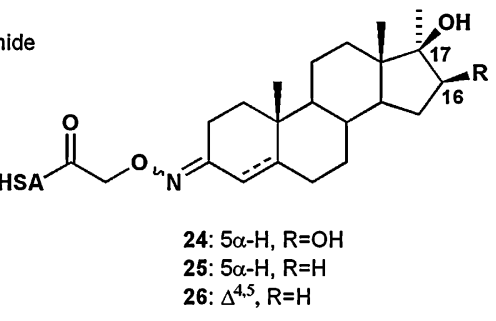

Succinimide ester derived conjugates

Fig. 11. Conjugation of steroids to HSA via two different peptide-coupling methods: direct carbodiimide activation or $N$-hydroxysuccinimide ester activation. 
The carboxylic acid moiety then enabled the steroids to be linked via peptide-coupling techniques to the lysine residues of HSA to provide the antigenic material.

Two peptide-coupling techniques were employed to link the steroid to the protein, as shown in Fig. 11. Firstly, the carboxylic acid 15-17 was coupled directly to HSA using in situ carbodiimide activation (EDC/DCC) to afford conjugates 21-23. Secondly, the activated $N$-hydroxysuccinimide ester method was utilised, as was first applied to certain steroids in their conjugation with BSA [35]. Hence, carboxylic acids 15-17 were converted to the activated esters 18-20 by treatment with $N$-hydroxysuccinimide in the presence of EDC. The activated esters 18-20, upon treatment with HSA, then gave conjugates 24-26. Low molecular weight impurities were removed from the conjugates by dialysis. In the case of $\mathbf{2 3}$ and 26, further fractionation of the conjugates was achieved by adjusting the $\mathrm{pH}$ to 4.5 , and separating the soluble from the insoluble material by centrifugation. As a result, 23a and 26a correspond to the fraction of the conjugates insoluble at $\mathrm{pH} 4.5$, and $\mathbf{2 3 b}$ and $\mathbf{2 6 \mathbf { b }}$ are the fractions soluble at this $\mathrm{pH}$.

The relative efficiencies of the two coupling methods (carbodiimide versus $N$-hydroxysuccinimide ester activation) were assessed using conjugates $\mathbf{2 3}$ and $\mathbf{2 6}$, which featured $\alpha, \beta$-unsaturated oxime moieties and were, therefore, suitable for UV analyses. The $\alpha, \beta$-unsaturated oxime of $\mathbf{1 7}$ was determined to have $\lambda_{\max }$ of $254 \mathrm{~nm}$, and the extinction coefficient $(\varepsilon)$ at this wavelength was determined to be $15,680 \mathrm{~L} \mathrm{~mol}^{-1}$. The steroid/HSA molar ratios were then determined for $\mathbf{2 3}$ and 26 by UV spectral analyses at $254 \mathrm{~nm}$ in $\mathrm{pH} 7.5$ buffer $(0.1 \mathrm{M})$. The absorbances of the conjugates were compared with that of HSA at the same concentrations, and calculations were performed by the method of Erlanger et al. [36] using a molecular weight of HSA as $66,462 \mathrm{~g} \mathrm{~mol}^{-1}$ and the extinction coefficient $(\varepsilon)$ for $\mathbf{1 7}$, which was assumed to remain the same when the steroids were conjugated to HSA. While this assumption is reported to give a relative error of $\sim 10 \%$ due to the shift in the steroid $\mathbf{1 7}$ absorption maximum upon conjugation [38,39], it remains constant for conjugates of a given type, thus enabling comparisons of the same conjugates produced by different methods [40]. The results of these steroidHSA molar ratio calculations are shown in Table 1 for 23a, 23b and 26a. The $\mathrm{pH} 4.5$ insoluble fraction 23a gave a higher molar ratio of steroid to HSA than the corresponding pH 4.5 soluble fraction $\mathbf{2 3 b}$, consistent with the protonation of the remaining free HSA lysine residues aiding water solubility in the latter. The highest ratio of steroid/HSA of 28 was obtained for $\mathrm{pH} 4.5$ insoluble fraction 26a. The higher molar ratio obtained for conjugate 26 versus 23 revealed that conjugation of steroid to protein was much more effective using the $\mathrm{N}$ hydroxysuccinimide ester activation (to give 26). In fact, by this method of activation, the $\mathrm{pH} 4.5$ soluble fraction $\mathbf{2 6 \mathbf { b }}$ contained very little soluble HSA conjugate, as indicated by the low absorbance of $\mathbf{2 6 \mathbf { b }}$ at $\lambda_{\max }$ of HSA of $208 \mathrm{~nm}$. At pH 4.5, a negligible amount of conjugate $\mathbf{2 6}$ was water soluble, as surface lysine residues were not available for protonation. The molar ratio of steroid/HSA was, therefore, not determined for 26b. These observations were consistent with the high level of conjugation achieved via the $N$-hydroxysuccinimide ester activation versus the carbodiimide activation method, and the high molar ratio observed for 26a. Hence, the $N$ hydroxysuccinimide ester activation maximises the number of steroid molecules attached to the protein surface. This is also consistent with the higher antibody titres (refer to Section 3.2) achieved for the conjugates $\mathbf{2 4}$ and $\mathbf{2 5}$ (derived via the $N$-hydroxysuccinimide ester method) versus those obtained for conjugates $\mathbf{2 1}$ and $\mathbf{2 2}$ (derived via the carbodiimide activation method), indicative of a higher steroid-HSA ratio for conjugates $\mathbf{2 4}$ and 25 versus 21 and 22.

\subsection{Antibody production and titre}

For each conjugate 21, 22, 24 and $\mathbf{2 5}$, four sheep were vaccinated and the sera collected. Antibody titres were then determined by an ELISA method. $16 \beta$-Hydroxymestanolone derivative 15 conjugated to ovalbumin was immobilised on plates and used in combination with antisera produced against conjugates $\mathbf{2 1}$ and $\mathbf{2 4}$, and the corresponding antibody titres determined. As shown in Table 2, sera from sheep vaccinated with conjugate $\mathbf{2 4}$ gave higher titres than sera from sheep given conjugate 21. Mestanolone derivative 16 immobilised on plates in the same way was used to determine antibody titres for antisera produced against conjugates $\mathbf{2 2}$ and $\mathbf{2 5}$ (refer to Table 2). The treatment with vaccine containing conjugate $\mathbf{2 5}$ gave higher antibody titres than vaccine containing 22. Conjugates $\mathbf{2 4}$ and $\mathbf{2 5}$ were produced by $\mathrm{N}$ hydroxysuccinimide coupling methods. The higher antibody titres observed using these conjugates also correlates with the higher steroid/protein molar ratio calculated for conjugate $\mathbf{2 6}$ versus that observed for $\mathbf{2 3}$ (Table 1, Sections 2.1.3 and 3.1). Hence, the $N$-hydroxysuccinimide coupling method gives a comparatively better conjugate for the production of antisera with high titres.

The sera from the two highest titre sheep per treatment were then collected and stored. The highest titre sera, raised in sheep against conjugates $\mathbf{2 4}$ and $\mathbf{2 5}$, were used in all subsequent ELISA experiments. The $16 \beta$-hydroxymestanolone plate used in combination with antisera produced against conjugate 24, constitutes the 16 $\beta$-hydroxymestanolone assay. The mestanolone plate used in combination with antisera against conjugate $\mathbf{2 5}$ forms the mestanolone assay.

\subsection{ELISA assay and cross-reactivity studies}

A number of anabolic steroids dissolved in assay buffer were tested by competition experiments using the $16 \beta$-hydroxymestanolone assay and the mestanolone assay, to assess cross-reactivities. The results for the $16 \beta$-hydroxymestanolone assay are shown in Table 3. High cross-reactivities (100-84\%) were observed for all $16 \beta, 17 \beta$-dihydroxy-17 $\alpha$ methyl steroids tested, therefore the antibody was highly specific for steroids 9 and 28-31, as shown in Fig. 12. 

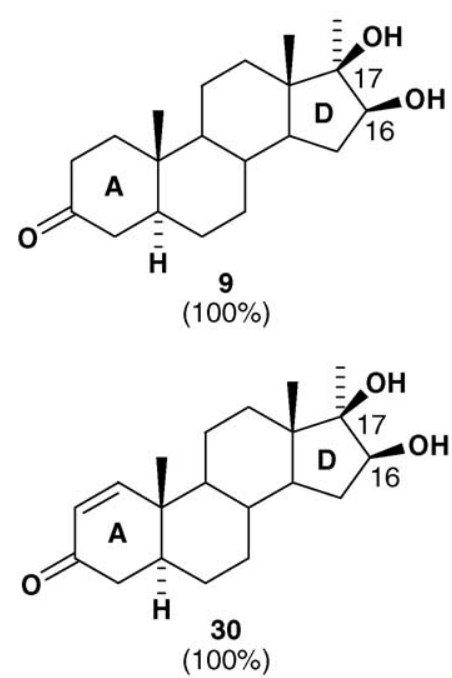
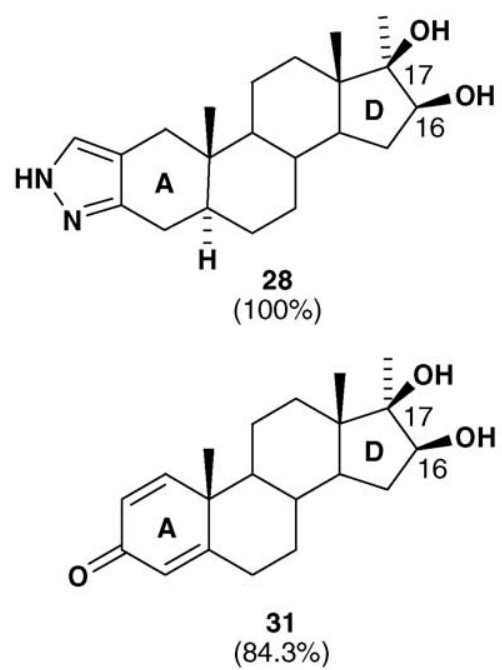
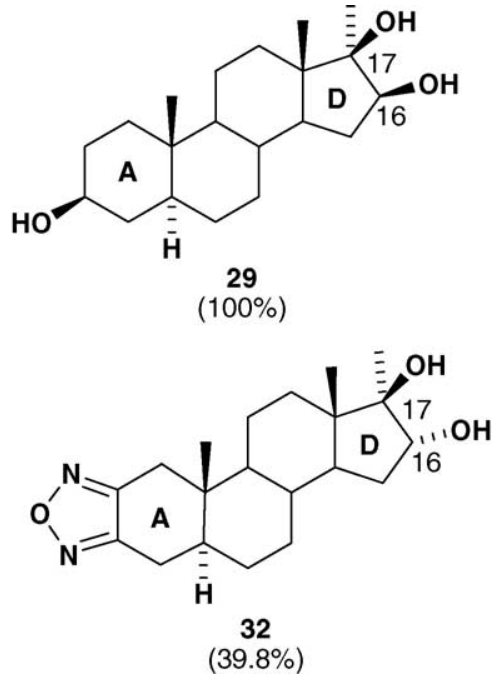

Fig. 12. Anabolic steroids with high cross-reactivities in the $16 \beta$-hydroxymestanolone assay.

Interestingly, one $16 \alpha, 17 \beta$-dihydroxy- $17 \alpha$-methyl steroid, namely $16 \alpha$-hydroxyfurazabol $\left(17 \alpha\right.$-methyl-1 $1^{\prime}, 2^{\prime}, 5^{\prime}-$ oxadiazolo $\left[4^{\prime}, 3^{\prime}: 2,3\right]-5 \alpha$-androstane- $16 \alpha, 17 \beta$-diol) $\quad(32)$, also showed significant cross-reactivity (39.8\%), whereas the other one tested, $17 \alpha$-methyl- $5 \alpha$-androstane- $3 \beta, 16 \alpha, 17 \beta$ triol exhibited low cross-reactivity (1.1\%). Of 50 additional steroids tested, all showed $<6 \%$ cross-reactivities. The antibodies raised against $\mathbf{2 4}$ showed low affinity for steroids that lacked a 16-hydroxy substituent, and/or those that lacked a $17 \alpha$-alkyl substituent. The 16,17-dihydroxy$17 \alpha$-ethyl steroids tested also gave low cross-reactivities (19-nor-5 $\alpha, 17 \alpha$-pregnane-3 $\beta, 16 \beta, 17 \beta$-triol $\quad(5.5 \%)$ and 19 -nor- $5 \alpha, 17 \alpha$-pregnane- $3 \beta, 16 \alpha, 17 \beta$-triol $\quad(<1 \%))$. The antibodies raised against $\mathbf{2 4}$ selectively recognise the $16 \beta, 17 \beta$-dihydroxy-17 $\alpha$-methyl D-ring structure common to many anabolic steroid metabolites, and so the $16 \beta$ hydroxymestanolone assay shows promise for the detection of this class of steroid metabolite.

The cross-reactivity results for the mestanolone assay, showing the specificity of the antibodies raised against $\mathbf{2 5}$, are shown in Table 4 . These antibodies showed significant crossreactivities for most $17 \beta$-hydroxy-17 $\alpha$-methyl steroids, although for this antibody, changes in the $\mathrm{A}, \mathrm{B}$ and $\mathrm{C}$ rings also influenced the cross-reactivities. For example, while $17 \alpha$-methyltestosterone gave a cross-reactivity of $100 \%$, a minor change in the A-ring in methandrostenolone (17 $\beta$ hydroxy-17 $\alpha$-methylandrost-1,4-dien-3-one) or in the B-ring in bolasterone ( $17 \beta$-hydroxy-7 $\alpha, 17 \alpha$-dimethylandrost-4-en3 -one) resulted in cross-reactivities of 28.1 and $25.2 \%$, respectively. $17 \beta$-Hydroxy- $17 \alpha$-ethynyl steroids also exhibited significant cross-reactivities. In general, for these antibodies, lower cross-reactivities were observed for steroids with a 16-hydroxy substituent and for steroids that lacked a $17 \alpha$-alkyl substituent. The cross-reactivities observed for $17 \beta$-hydroxy- $17 \alpha$-ethyl steroids were mixed. Hence, the antibodies raised against 25 recognise the 17ß-hydroxy-
$17 \alpha$-methyl D-ring structure common to many parent anabolic steroids, but were not as selective as the $16 \beta$ hydroxymestanolone assay. As a consequence, some endogenous steroids, e.g. testosterone, which may be excreted in high concentrations, may be problematic in the mestanolone assay despite relatively low cross-reactivities (e.g. testosterone $(5.6 \%)$ ).

\subsubsection{Validity of the cross-reactivity studies}

As shown in Figs. 4 and 5 , the $B / B_{0} \%$ absorbances were determined by the ELISA assays for a number of the cross-reactive anabolic steroid standards, together with the original steroid, $16 \beta$-hydroxymestanolone (for the $16 \beta$ hydroxymestanolone plate) or mestanolone (for the mestanolone plate). Plots of percentage absorbance versus concentration show that those steroid standards that had significant cross-reactivity ran parallel to the original compounds. By contrast, those steroid standards that were less crossreactive did not follow this trend. These results indicated that the cross-reactivity comparisons were valid for these assays.

\subsection{Application to administration urine samples}

Stanozolol (4) and methandriol (27) (refer to Fig. 13) were administered to horses and the urine samples were then analysed by the $16 \beta$-hydroxymestanolone assay to assess detection of the $16 \beta$-hydroxy metabolites. Urine samples post methandriol (27) administration were analysed by the mestanolone assay, GCMS and the 16 $\beta$-hydroxymestanolone assay.

Because of low urinary excretion and rapid metabolism, stanozolol (4) is difficult to detect in urine. Instead, methods of detecting metabolites of $\mathbf{4}$ have been sought. The metabolites are mostly excreted as glucuronide or sulfate conjugates. Hence, enzymatic hydrolysis and extraction procedures pre- 

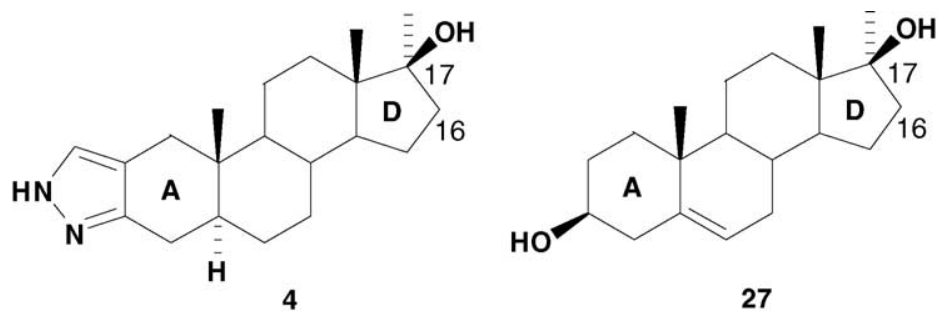

Fig. 13. Anabolic steroids administered to horses for analysis of equine urine via the $16 \beta$-hydroxymestanolone and mestanolone assays.

cede LCMS detection techniques with derivatisations also required for GCMS detection methods [28].

Since $16 \beta$-hydroxystanozolol showed $100 \%$ crossreactivity to the $16 \beta$-hydroxymestanolone antigen, equine urine post-stanozolol (4) administration was analysed by the $16 \beta$-hydroxymestanolone assay to screen for the presence of 16ß-hydroxystanozolol. Analysis of raw urine produced negative results. However, this is consistent with existing methods of analysis, which require hydrolysis and extraction procedures to release stanozolol metabolites present as glucuronide or sulfate conjugates [28].

Therefore, the raw urine was hydrolysed overnight with a $1 / 100$ dilution of $\beta$-glucuronidase and then assayed. The absorbances obtained in the assays during the days post-administration are shown in Fig. 6(a). A decrease in absorbance, relative to the negative control (day 0), is indicative of competition between a substance in the urine sample and the parent antigen, for binding to the antibody. Similar suppressed absorbances were observed with different batches of $\beta$-glucuronidase hydrolysed raw urine and different batches of ELISA plates, and showed the "saw tooth" excretion pattern typically observed for long-acting anabolic steroid depot preparations [20,41-44]. Hence, cross-reacting stanozolol metabolites were detected in the assay.

The raw urine was then subjected to reverse-phase SPE, methanolysed and quenched with $\mathrm{pH} 8$ buffer and analysed again in the $16 \beta$-hydroxymestanolone assay. A further extraction of the residual quenched solvolysate (by mixed-mode reverse-phase/cation exchange SPE) was carried out and the basic extract also analysed in the $16 \beta$ hydroxymestanolone assay. The absorbances obtained in the assays during the days post-administration are shown in Figs. 6(b and c). Again, decreased absorbances are observed relative to the negative control, with the excretion profile matching that observed by the standard LCMS method [20]. Since unmetabolised stanozolol (4) gives negligible crossreactivity (refer to Table 3 ) and dihydroxylated stanozolol metabolites were not previously detected in equine urine samples $[17,20]$, a comparison with the standard LCMS procedure [20] indicates the detections (particularly as in Fig. 6(c)), were primarily due to $16 \beta$-hydroxystanozolol.

Methandriol (27) was administered to a horse and its urine was assessed via the mestanolone assay. Urine was analysed raw and following $\beta$-glucuronidase hydrolysis via the mestanolone assay, but negative results were obtained. Again, metabolites are present significantly as glucuronide and sulfate conjugates, although the negative result following the hydrolysis step is consistent with interference by endogenous materials. Hence, the raw urine was extracted (SPE), methanolysed and quenched (as per stanozolol administered urine). Further extraction (SPE) of the quenched solvolysate was carried out, and both the quenched solvolysate and the neutral extract from subsequent SPE were analysed via the mestanolone assay. Suppressed absorbance readings were obtained up to 35 days post-administration for both extracts (Fig. 7). Hence, methandriol metabolites, presumably featuring a $17 \beta$-hydroxy-17 $\alpha$-methyl substituted D-ring, were detected by the mestanolone assay up to 35 days later. Analysis of the quenched solvolysate by GCMS revealed that methandriol (27) constituted the major component, and its excretion curve is shown in Fig. 9. The typical "saw tooth" pattern [20,41-44] observed correlates well with the pattern observed by the mestanolone assay.

In humans, methandriol (27), in contrast to stanozolol (4), undergoes extensive metabolism in the $\mathrm{A}$ and $\mathrm{B}$ rings, including double bond isomerisation, oxidation and reductions, with $17 \alpha$-methyltestosterone thought to be intermediary [24]. As shown in Table 4, methyltestosterone and $17 \alpha$-methyl$5 \alpha$-androstane- $3 \beta, 17 \beta$-diol, both potential metabolites of methandriol, both showed $100 \%$ cross-reactivity in the mestanolone assay. Methandriol itself also showed high crossreactivity of $78.7 \%$. Hence, the assay would be expected to detect these metabolites. Studies on the metabolism of $17 \alpha$-methyltestosterone in the horse have identified metabolites with and without further hydroxylation of the Dring $[16,18,19]$, but further D-ring hydroxylated metabolites would not be detected in this assay, as the cross-reactivities for such compounds were low (refer to Section 3.3). Only trace amounts of methyltestosterone and methylandrostanediols were detected in the GCMS analysis, and hence it is likely that the excretion of methandriol (27) accounts for the ELISA result.

In order to detect methandriol metabolites resulting from hydroxylation of the D-ring at position 16, the quenched solvolysate and neutral extract from subsequent SPE were also analysed by the 16ß-hydroxymestanolone assay, as shown in Fig. 8. As indicated by the suppressed absorbances, a metabolite or metabolites that cross-reacted with the plate were detected through to day 42 . Further work will ascertain whether the presence of $16 \beta$-hydroxylated metabolites 
of methandriol in the urine account for this suppression of absorbance.

\section{Conclusion}

The ELISA methods developed are an effective screening tool for routine detection of new and known anabolic steroids and their metabolites in equine urine. In particular, the $16 \beta$ hydroxymestanolone assay specifically detects a common D-ring metabolite structure of $17 \alpha$-methyl steroids. The mestanolone assay detects the corresponding parent steroids. Further assays will be developed involving antibodies raised against the 16 $\alpha$-hydroxymestanolone D-ring structure and also against alternate 17-alkyl steroids and metabolites (e.g. ethyl or ethynyl) to broaden the scope of the screen, with potential to detect new designer steroids and metabolites, such as tetrahydrogestrinone.

\section{Acknowledgements}

This work was supported by the Australian Racing Forensic Laboratory and the Australian Research Council Linkage Grant Scheme.

\section{References}

[1] D.H. Catlin, M.H. Sekera, B.D. Ahrens, B. Starcevic, Y.-C. Chang, C.K. Hatton, Tetrahydrogestrinone: discovery, synthesis, and detection in urine, Rapid Commun. Mass Spectrom. 18 (12) (2004) $1245-1249$.

[2] P. Delahaut, P. Jacquemin, Y. Colemonts, M. Dubois, J. De Oraeve, H. Oeluyker, Quantitative determination of several synthetic corticosteriods by gas chromatography-mass spectrometry after purification by immunoaffinity chromatography, J. Chromatogr. B: Biomed. Sci. Appl. 696 (1997) 203-215.

[3] M. Machnik, P. Delahaut, S. Horning, W. Schänzer, Purification and concentration of anabolic steroids by immuno affinity chromatography (IAC), in: W. Schänzer, (Ed.), Recent Adv. Doping Anal. (4). Proc. 14th Cologne Workshop on Dope Analysis, Sport und Buch Strauss, Köln, 1997, pp. 223-237.

[4] T.L. Fodey, C.T. Elliott, S.R.H. Crooks, W.J. McCaughey, The appraisal of an automated multi-immunoaffinity chromatography system to detect anabolic agents in bile and urine, Food Agric. Immunol. 8 (3) (1996) 157-167.

[5] W. Haasnoot, S.M. Ezkerro, H. Keukens, Application of immunochemical selectivity for screening and confirmation of animal drug residues in biological samples, Residues Vet. Drugs Food. Proc. EuroResidue Conf. 2 (1993) 347-351.

[6] A. Farjam, J.J. Vreuls, W.J.G.M. Cuppen, U.A.T. Brinkman, G.J. de Jong, Direct introduction of large-volume urine samples into an on-line immunoaffinity sample pretreatment-capillary gas chromatography system, Anal. Chem. 63 (21) (1991) 2481-2487.

[7] E.H.J.M. Jansen, R.H. Van den Berg, G. Zomer, R. Both-Miedema, C. Enkelaar-Willemsen, R.W. Stephany, Combination of highperformance liquid chromatography and chemiluminescent immunochemical detection of hormonal anabolics and their metabolites, Anal. Chim. Acta 170 (1) (1985) 21-27.
[8] E.H.J.M. Jansen, C.A. Laan, R.H. Van den Berg, R.W. Stephany, G. Somer, A solid-phase chemiluminescence immunoassay for $17 \alpha-$ methyltestosterone, Anal. Chim. Acta 170 (1) (1985) 29-34.

[9] M. Dubois, X. Taillieu, Y. Colemonts, B. Lansival, P. Oclahaut, J. De Graeve, P. Delahaut, GC-MS determination of anabolic steroids after multi-immunoaffinity purification, Analyst 123 (1998) 2611-2616.

[10] S.S. Hassan, F.J. Rowell, P. Hambleton, L.S. Jackson, A rapid onfilter immunoassay screen for dexamethasone in equine urine, Anal. Commun. 35 (1998) 249-252.

[11] C.S. Creaser, S.J. Feely, E. Houghton, M. Seymour, Immunoaffinity chromatography combined online with high-performance liquid chromatography-mass spectrometry for the determination of corticosteroids, J. Chromatogr. A. 794 (1998) 37-43.

[12] L.M. Ribeiro Neto, M.C. Salvadori, H.S. Spinosa, Immunoaffinity chromatography in the detection of dexamethasone in equine urine, J. Chromatogr. Sci. 35 (1997) 549-551.

[13] M.W. Elmlinger, M.B. Ranke, M.M. Weber, Detection of free urinary cortisol by means of immunoassays in the diagnosis of adrenocortical disorders. Is extraction of urine necessary? Clin. Lab. 43 (1997) $857-862$.

[14] X. Gu, M. Meleka-Boules, C.L. Chen, Micellar electrokinetic capillary chromatography combined with immunoaffinity chromatography for identification and determination of dexamethasone and flumethasone in equine urine, J. Capillary Electrophor. 3 (1996) 43-49.

[15] S.M.R. Stanley, B.S. Wilhelmi, J.P. Rodgers, H. Bertschinger, Immunoaffinity chromatography combined with gas chromatography-negative ion chemical ionization mass spectrometry for the confirmation of flumethasone abuse in the equine, J. Chromatogr., Biomed. Appl. 614 (1993) 77-86.

[16] M.C. Dumasia, In vivo biotransformation of $17 \alpha$-methyltestosterone in the horse revisited: identification of 17-hydroxymethyl metabolites in equine urine by capillary gas chromatography/mass spectrometry, Rapid Commun. Mass Spectrom. 17 (2003) 320-329.

[17] W.M. Mück, J.D. Henion, High-performance liquid chromatograph/tandem mass spectrometry: its use for the identification of stanozolol and its major metabolites in human and equine urine, Biomed. Environ. Mass Spectrom. 19 (1) (1990) 37-51.

[18] C. Schoene, A.N.R. Nedderman, E. Houghton, Preliminary study of the metabolism of $17 \alpha$-methyltestosterone in horses utilizing gas chromatography-mass spectrometric techniques, Analyst 119 (12) (1994) 2537-2542.

[19] S.M.R. Stanley, L. Smith, J.P. Rodgers, Biotransformation of 17alkylsteroids in the equine: gas chromatographic-mass spectral indentification of ten intermediate metabolites of methyltestosterone, J. Chromatogr. B: Biomed. Sci. Appl. 690 (1997) 55-64.

[20] A.R. McKinney, C.J. Suann, A.J. Dunstan, S.L. Mulley, D.D. Ridley, A.M. Stenhouse, Detection of stanozolol and its metabolites in equine urine by liquid chromatography-electrospray ionization ion trap mass spectrometry, J. Chromatogr. B. 811 (2004) 75-83.

[21] A.R. McKinney, D.D. Ridley, C.J. Suann, The metabolism of norethandrolone in the horse: characterization of 16-, 20- and 21oxygenated metabolites by gas chromatography/mass spectrometry, J. Mass Spectrom. 36 (2001) 145-150.

[22] A.R. McKinney, D.D. Ridley, P. Turner, Equine metabolites of norethandrolone: synthesis of a series of 19-nor-17 $\alpha$-pregnanediols and 19-nor-17 $\alpha$-pregnanetriols, Aust. J. Chem. 56 (2003) 829838.

[23] A.R. McKinney, D.D. Ridley, Synthesis of equine metabolites of anabolic steroids: reformatsky reactions on estran-17-ones, Aust. J. Chem. 54 (2001) 757-761.

[24] W. Schänzer, M. Donike, Metabolism of anabolic steroids in man: synthesis and use of reference substances for identification of anabolic steroid metabolites, Anal. Chim. Acta 275 (1993) 23-48.

[25] W. Schänzer, P. Delahaut, H. Geyer, M. Machnik, S. Horning, Longterm detection and identification of metandienone and stanozolol abuse in athletes by gas chromatography-high-resolution mass spectrometry, J. Chromatog. B., Biomed. Appl. 687 (1996) 93-108. 
[26] M. Van Puymbrocck, M.E.M. Kuilman, R.F.M. Maas, R.F. Witkamp, L. Leyssens, A.S.J.P.A.M. Van Miert, L. Hendriks, D. Vanderzande, P. Adriaensens, M.-P. Jacobs, J. Raus, $17 \alpha$-Ethyl-5 $\beta$-estrane- $3 \alpha, 17 \beta-$ diol, a biological marker for the abuse of norethandrolone and ethylestrenol in slaughter cattle, J. Chromatogr. B: Biomed. Sci. Appl. 728 (1999) 217-232.

[27] R.J. Ward, A.M. Lawson, C.H.L. Shackleton, Metabolism of anabolic steroid drugs in man and the Marmoset monkey (Callithrix jacchus)-I. Nilevar and orabolin, J. Steroid Biochem. 8 (1977) 1057-1063.

[28] S. Poelmans, K. De Wasch, H.F. De Brabander, M. Van De Wiele, D. Courtheyn, L.A. van Ginkel, S.S. Sterk, Ph. Delahaut, M. Dubois, R. Schilt, M. Nielen, J. Vercammen, S. Impens, R. Stephany, T. Hamoir, G. Pottie, C. Van Poucke, C. Van Peteghem, Analytical possibilities for the detection of stanozolol and its metabolites, Anal. Chim. Acta 473 (2002) 39-47.

[29] T. Takegoshi, Investigations on steroids XIII. Synthesis of the compounds related to the metabolites of furazabol (17ß-hydroxy$17 \alpha$-methyl-5 $\alpha$-androstano[2,3-c]furazan, Chem. Pharm. Bull. 20 (6) (1972) 1260-1271.

[30] N.S. Leeds, D.K. Fukushima, T.F. Gallagher, Studies of steroid ring $\mathrm{D}$ epoxides of enol acetates; a new synthesis of estriol and of androstane-3 $\beta, 16 \alpha, 17 \beta$-triol, J. Am. Chem. Soc. 76 (1954) 2943-2948.

[31] M. Numazawa, M. Shelangouski, M. Nakakoshi, Production of 16 $\beta$ (acetoxy)acetoxy derivatives by reaction of 17-keto steroid enol acetates with lead (IV) acetate, Steroids 66 (1) (2001) 743-748.

[32] R.H. Mazur, 3-Hydroxyimino-17 $\alpha$-(lower alkyl)-5 $\alpha$-androstan-17 $\beta$ ols and the optionally substituted 3-acyloxymino and 3-alkoxyimino derivatives corresponding, US Patent 3,211,756 (1965).

[33] P.A. Wilson, J.M. George, R.I. Cox, R.M. Hoskinson, R.J. Scaramuzzi, Fecundity of domestic livestock, US Patent 4,331,657 (1982).

[34] S. Yamauchi, M. Kojima, F. Nakayama, Preparation and antigenic property of 3-dehydrolithocholylglycine 3-( $O$-carboxymethyl)oximebovine serum albumin conjugate, Steroids 41 (2) (1983) 165-172.

[35] H. Hosoda, Y. Sakai, H. Yoshida, S. Miyairi, K. Ishi, T. Nambara, The preparation of steroid $N$-hydroxysuccinimide esters and their reactivities with bovine serum albumin, Chem. Pharm. Bull. 27 (3) (1979) 742-746.
[36] B.F. Erlanger, F. Borek, S.M. Beiser, S. Lieberman, Steroid-protein conjugates I. Preparation and characterisation of conjugates of bovine serum albumin with testosterone and with cortisone, J. Biol. Chem. 228 (1957) 713-727.

[37] P.W. Tang, D.L. Crone, A new method for hydrolyzing sulfate and glucuronyl conjugates of steroids, Anal. Biochem. 182 (1989) 289-294.

[38] U. Westphal, Steroid-protein interactions III. Spectrophotometric demonstration of interaction between proteins and progesterone, deoxycorticosterone and cortisol, Arch. Biochem. Biophys. 66 (1957) 71-90.

[39] U. Westphal, B.D. Ashley, Steroid-protein interactions IV. Influence of functional groups in $\Delta^{4}$-3-ketosteroids on interaction with serum albumin and $\beta$-lactoglobulin, J. Biol. Chem. 233 (1958) 57-62.

[40] E.A. Yatsimirskaya, E.M. Gavrilova, A.M. Egorov, A.V. Levashov, Preparation of conjugates of progesterone with bovine serum albumin in the reversed micellar medium, Steroids 58 (1993) 547-550.

[41] J.M. Jouany, Y. Bonnaire, P. Plou, P. Silberzahn, C. Boudene, Metabolic profiles of anabolic steroids in racehorse urine, in: D.L. Crone (Ed.), Proceedings of the Sixth International Conference of Racing Analysts and Veterinarians, Hong Kong, MacMillan Publishers, Hong Kong, 1987, pp. 233-239.

[42] D.C. Batty, K.E. Mason, J.H. Vine, Testosterone-the Victorian experience, in: C.R. Short (Ed.), Proceedings of the Ninth International Conference of Racing Analysts and Veterinarians, vol. 1, New Orleans, USA, Louisiana State University, Baton Rouge, 1992, pp. $45-55$.

[43] J.M. Ralston, S. Ngo, A.M. Stenhouse, Detection of 19nortestosterone in equine and greyhound urine, in: C.R. Short (Ed.), Proceedings of the Ninth International Conference of Racing Analysts and Veterinarians, vol. 1, New Orleans, USA, Louisiana State University, Baton Rouge, 1992, pp. 69-73.

[44] Y. Bonnaire, L. Dehennin, P. Plou, M.A. Popot, P.L. Toutain, Study of testosterone and metabolites in urine and plasma after administration of a single dose of testosterone hexahydrobenzoate to mares: a new approach, in: P. Kallings, U. Bondesson, E. Houghton (Eds.), Proceedings of the 10th International Conference of Racing Analysts and Veterinarians, Stockholm, Sweden, R\&W Publications, Newmarket, 1995, pp. 187-194. 